\title{
Persistence of tree relicts in the Spanish Central System through the Holocene
}

\author{
Daniel Abel Schaad (*), Fernando Pulido (**), José Antonio López-Sáez (*), \\ Francisca Alba Sánchez (***), Diego Nieto Lugilde (***), \\ Fátima Franco Múgica (****), Sebastián Pérez Díaz (*****), M. Blanca Ruiz \\ Zapata (******), M. José Gil García (******) \& Miriam Dorado Valiño (*)
}

\begin{abstract}
Abel Schaad, D., Pulido, F., López-Sáez, J.A., Alba Sánchez, F., Nieto Lugilde, D., Franco Múgica, F., PérezDíaz, S., Ruiz Zapata, M.B., Gil García, M.J. \& Dorado Valiño, M. Persistence of tree relicts in the Spanish Central System through the Holocene. Lazaroa 35: 107-131 (2014).

Persistence of relict tree species in Mediterranean environments is becoming increasingly unlikely in view of ongoing and future global change. The variability in the Holocene climate and more recent anthropogenic impacts have driven many populations to fragmentation and isolation, and even to extinction. However, some have persisted to the present day. The understanding of their evolution requires long-term studies, in which pollen analysis is a key approach both for formulating hypotheses and supporting results from other disciplines. Mountain ranges have played and still play an essential role as both glacial and interglacial refugia during the Quaternary. The Spanish Central System harbors an exceptional diversity due to its geographical location and complex topography. Some cold-adapted species have survived here with significant proportions of their southernmost populations, often displaying striking adaptations to their changing environments. This work contains a comprehensive review of the palynological investigations conducted in the Spanish Central System, and reveals the distribution of genera such as Taxus, Betula, Fagus, Carpinus and Tilia throughout the Holocene. We also highlight the scarcity of well-dated and high-resolution works, which may contribute to a better understanding of their recent and future evolution.
\end{abstract}

Keywords: Tree relicts, Taxus, Betula, Fagus, Carpinus, Tilia, Spanish Central System, Holocene, Pollen analyses

Resumen: Abel Schaad, D., Pulido-Díaz, F.J., López-Sáez, J.A., Alba Sánchez, F., Nieto Lugilde, D., Franco Múgica, F., Pérez Díaz, S., Ruiz Zapata, M.B., Gil García, M.J. \& Dorado Valiño, M. Persistencia de especies arbóreas relictas a lo largo del Holoceno en el Sistema Central español. Lazaroa 35: 107-131 (2014).

La persistencia de especies forestales relictas en ambientes mediterráneos es cada vez más incierta, especialmente en escenarios actuales de cambio global. La variabilidad del clima en el Holoceno y, más recientemente, los impactos antrópicos han llevado a muchas poblaciones a la fragmentación y el aislamiento, e incluso a la extinción, aunque algunas de ellas han permanecido hasta la actualidad. El conocimiento de su evolución requiere de estudios a largo plazo, entre los cuales el análisis polínico supone una aproximación importante, tanto para formular hipótesis como para verificar los resultados obtenidos en otras disciplinas. Por otra parte, las cadenas montañosas han jugado, y aún juegan, un papel esencial como refugios glaciales o interglaciales durante el Cuaternario. El Sistema Central español alberga una diversidad excepcional debido a su posición geográfica y a su compleja topografía. Algunas especies adaptadas al frío tienen aquí una parte importante de sus poblaciones más meridionales, que probablemente muestran interesantes adaptaciones a los ambientes cambientes. En este trabajo, una exhaustiva recopilación de las investigaciones palinológicas desarrolladas a lo largo del

* Grupo de Investigación Arqueobiología. Instituto de Historia, CCHS, CSIC. C/ Albasanz 26-28, E-28037 Madrid. E-mail: dabe1222@hotmail.com

** Grupo de Investigación Forestal. Centro Universitario de Plasencia Universidad de Extremadura. Avda. Virgen del Puerto 2, E-10600 Cáceres.

*** Departamento de Botánica. Facultad de Ciencias. Universidad de Granada E-18071 Granada / Ecoinformatics \& Biodiversity Group. Department of Bioscience, Aarhus University (Aarhus, Denmark)

**** Departamento de Ecología. Universidad Autónoma de Madrid. E-28049 Madrid.

***** GEODE, UMR 5602 CNRS, Université Toulouse-Le Mirail, 31058 Toulouse, France/ Universidad del País Vasco (UPV/EHU). E-01006 Vitoria-Gasteiz.

****** Departamento de Geología. Universidad de Alcalá de Henares. E-28871 Alcalá de Henares. 
Sistema Central español muestra la distribución de géneros como Taxus, Betula, Fagus, Carpinus y Tilia durante el Holoceno, y asimismo llama la atención sobre la escasez de trabajos bien datados y de alta resolución, que podrían mejorar el conocimiento de su evolución reciente y futura.

Palabras clave: especies arbóreas relictas, Taxus, Betula, Fagus, Carpinus, Tilia, Sistema Central español, Holoceno, Análisis polínicos.

\section{INTRODUCTION}

\section{POLLEN RECORDS AND RELICT SPECIES}

Besides the evolution of the dominant tree taxa throughout the Holocene in the Mediterranean region, pollen analyses record sporadically the presence of some types (i.e. Taxus, Betula, Fagus, Carpinus, Tilia) representing species that currently grow in isolated pockets, usually at high altitudes close to watercourses. Some of them are already extinct and the future of the remaining ones is uncertain (HAMPE \& PeTiT, 2005; ThuILLER \& al., 2008; AlLEN \& al., 2009; AsHCROFT, 2010; GotTFried \& al., 2012; RuIZ-LABOURTDETTE\& al., 2012; PÉREZ-DíAZ \& al., 2013). The factors underlying the persistence of these taxa is increasingly gaining more attention from researchers as they could shed light on current debate on climate change, tree phylogeography, response to disturbances, evolutionary adaptations or future conservation strategies (THUILlER \& al., 2008; PEARMAN \& al., 2008; Postigo \& al., 2010; StEWART \& al., 2010; GotTFRIED \& al., 2012).

Cold-adapted tree species have been considered as climate relicts (HAMPE \& JuMP, 2011, LÓPEZ-SÁEZ \& al., 2013), growing in suitable sites, surrounded by unhospitable habitats under distinct environmental conditions. Such locations can often constitute local refuges, as they maintain, presumably for a long time, favorable features which are absent in the surrounding landscape (BENNET \& PROVAN, 2008; STEWART \& al., 2010; DOBROWSKI, 2011; WiLLIS \& MACDONALD, 2011; KEPPEL \& al., 2012).

Climatic and anthropogenic disturbances have conditioned the persistence of tree populations since the Last Glacial Maximum (TURNER \& al., 2008; GIESECKE \& al., 2011; PÉREZ-OBIOL \& al., 2011; HENNE \& al., 2013; JOANNIN \& al., 2012; COLOMBAROLI \& al., 2013). The responses of tree species to these changes depend on environmental factors but also on species-specific life history traits (LAVERGNe \& al., 2010; HAMPE \& JuMP, 2011). Regarding environmental factors, mountains are "natural laboratories" (JuMP \& al., 2009) for the study of distribution shifts because of their strong altitudinal zonation and high climatic sensitivity (PARMESAN, 2006; PÉREZ-OBIOL \& al., 2011). They also support habitat mosaics and contain steep climatic gradients allowing the decoupling from regional climatic patterns (DoBRowski, 2011; Nieto-Feliner, 2011). This spatial heterogeneity promotes a high biodiversity (KöRNER \& OHSAWA, 2005; MÈDAIL \& DiAdEMA, 2009) and also range shifts (ROBLEDO-ARNUNCIO \& al., 2005; HAMPE \& JUMP, 2011; LENOIR \& SVENNING, 2013). In addition, East-West orientation of mountain ranges enhances microclimatic amplitude (GÓMEZ \& LUNT, 2007; STEWART \& al., 2010). Thus, the Spanish Central System (hereafter SCS) is a straightforward scenario to assess the recent evolution of these relict populations, especially of those located at the southernmost range limits (LóPEZ-SÁEZ, 1993; LÓPEZ-SÁEZ \& López-García, 1994; Hampe \& Petit, 2005; Petit \& al., 2005; Thuiller \& al., 2008; PAUTASSO, 2009).

Among species features favoring persistence, dispersal-related traits have been highlighted (Bhagwat \& Willis, 2008; Hampe \& Jump, 2011), as well as thermal and drought tolerances (AitKen \& al., 2008; Allen \& al., 2009; SANZ \& al., 2009; LAVERGNe \& al., 2010; DobrowsKi, 2011). Species may respond to disturbances through migration, adaptation or extinction (PARMESAN, 2006; THUILLER \& al., 2008; AlBA-SÁNCHEZ \& al., 2010; WILLIS \& MACDONALD, 2011). There are evidences of Holocene extinctions and elevational shifts (RoBlEDO-ARNUNCIO \& al., 2005; AITKEN \& al., 2008; JUMP \& al. 2009; WILlis ANd Macdonald, 2011; Abel SchaAd, 
2012), while adaptative and plastic responses are not yet well understood (DAVIS \& al., 2005; JUMP \& al., 2009; LAVERGNE \& al., 2010; HAMPE \& JuMP, 2011; LENOIR \& SVENNING, 2013).

Palaeoecological information from pollen records provides a reliable tool to interpret the longterm distribution patterns of tree species, as fossil evidence is needed to give a non- speculative explanation. Thus, it is extensively used both to formulate hypothesis and support results from other approaches (DAVIS \& al., 2005; SVENNING \& al., 2011; Willis \& Macdonald, 2011; KePpel \& $a l ., 2012)$. In this paper, a comprehensive review of pollen records of Betula, Carpinus, Fagus, Taxus and Tilia in the SCS is presented, in order to show their evolution throughout the Holocene as well as their responses to climatic and anthropogenic disturbances. Pollen records of Fagus in the SCS somehow question the theories about its Late Holocene expansion from northern populations. Thus, a Species Distribution Model has also been developed to better illustrate this issue.

\section{MAIN FEATURES OF HOLOCENE VEGETATION INTHE SCS}

Holocene records spanning back beyond the last 6,000 years are scarce in the SCS (RuIZ-ZAPATA \& al., 1998). Nonetheless, an overall pattern of the evolution of vegetation throughout the Holocene can be established. The oceanic influence defines distinct landscapes along a west-east gradient (Franco Múgica, 1995; Gavilán \& al., 1998; ABEl SchaAd, 2012).

The Early Holocene is characterized by the spread of birch forests in the western sector and the prevalence of pinewoods eastwards. The presence of mesophilous taxa like Quercus or Corylus increases westwards, due to milder climatic conditions.

The Middle Holocene is a period of more stable climate (CHEDDADI \& al., 1997; BREWER \& al., 2009; CARRIÓN \& al., 2010; VANNIERE \& al., 2011; MAGNY \& al., 2012), disrupted by the first evidences of human impact on the landscape. The first traces of agriculture are found around $5000 \mathrm{cal} \mathrm{yr} \mathrm{BP}$. From the Chalcolithic (5300-3900 cal yr BP) onwards a more extensive land use is recorded, trig- gering the clearance of forests to conduct farming and grazing activities (LóPEZ-SÁEZ \& al., 2013).

An increasing human pressure is recorded in the Late Holocene, especially during Roman times, with a large-scale deforestation of mid-altitude areas and the cultivation of sweet chestnut and olive groves. In the Middle Ages shrublands spread mainly in high-altitude areas, also with a distinct geographical pattern: heathlands on the western sector and in the easternmost ranges (Ayllón and Pela), and broom communities in the central ones. This high anthropic impact blurs the climatic influence on vegetation whereas humaninduced fires, grazing and, more recently, the growth of forest crops, become the major drivers of landscape change (LÓPEZ-SÁEZ \& al., 2013).

\section{MATERIAL AND METHODS}

\section{STUdy AREA}

The SCS (Figure 1) is a mountain range approximately $400 \mathrm{~km}$ long which divides the Duero and Tajo basins (PEDRAZA \& CARRASCO, 1999), with a WSW-ENE general layout (RIVAS-MARTíNEZ \& al., 1987; UBANELL, 1994). It consists of a series of mountain ranges ("sierras") separated by depressions or troughs which represent natural corridors between the two subplateaus (DE VICENTE \& al., 1994; PEDRAZA \& CARRASCO, 1999; Martín Velázquez \& Elorza, 2007). It is a chain of sunken or elevated blocks (PEDRAZA, 1994; Muñoz Barco \& Martínez Flores, 2005), which, according to the materials, granitic or metamorphic, is sorted out in different tectonic styles (DE ViCENTE \& al., 1994). Related to this dynamics is the asymmetry between the northern and southern slopes of the mountain range, particularly in the western sector, because of the altitude of the northern plateau respect to the deeply-set valleys in the Tagus basin (MUÑOZ BARCo \& MARTínez Flores, 2005). Glacial morphologies are also present at the highest alevation areas of the range, above 1900 masl (PEDRAZA \& CARRASCO, 2006). Along with these processes, modeling by fluvial erosion has essentially set the current relief (APALATEGUI \& al., 2006). 


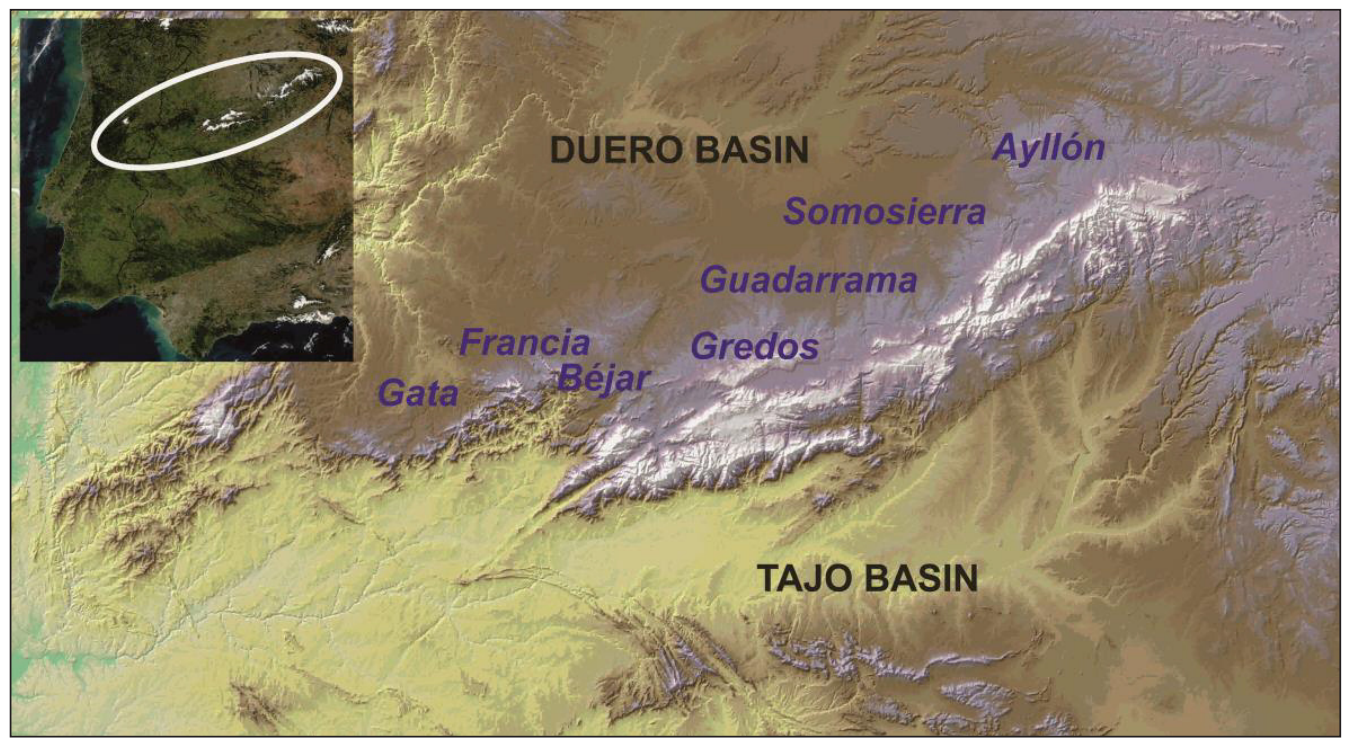

Figure 1. - Main mountain ranges forming the Spanish Central System.

The climate is of a Mediterranean type, characterized by a summer drought period lasting 3-5 months and more intense rainfall in autumn and winter (Devesa AlCARAZ, 1995). As for temperatures, there are more thermic conditions on the southern slopes, thanks to its lower elevation and greater sun exposure. Furthermore, there is a continentality gradient which tends to increase from more western areas, near the Atlantic coast, inland (Peinado LorCa \& Rivas-Martínez, 1987; GAVILÁN \& al., 1998). Dominant southwest humid winds cause, similarly, a greater abundance of precipitation on the southern slopes (GAVILÁN \& al., 1998). Differences in altitude offset in many cases the influence of these gradients.

Vegetation is dominated by oak forests of Quercus pyrenaica, especially in the western sector at mid altitudes. In the lowlands, these forests contact with holm oak $(Q$. ilex) and cork oak $(Q$. suber) woodlands. Above them, different $Q$.pyrenaica communities develop according to rainfall ranges. To the east, pine forests acquire greater prominence, especially in the mountains of Gredos and Guadarrama, where P. sylvestris stands represent the timberline. Altitudes over 1.600 masl are widely occupied by shrublands, where brooms like Cytisus oromediterraneus, Echinospartum ibericum, E. barnadesii or, in more humid areas, heathlands mostly composed by Erica australis, constitute the main features of the landscape. Finally, grasslands are the dominant vegetation in the highest areas.

\section{POLLEN REVIEW}

A comprehensive review of all available pollen records (Table 1), both from natural and archaeological sites, in the SCS (LóPEZ-SÁEZ \& al., 2013) has been carried out. We focused our attention in the presence of Betula, Taxus, Fagus, Carpinus and Tilia pollen types. Calibrated radiocarbon dates are given as cal yr BP. Whenever the authors present their own age-depth model it has been followed in the text. In those sites with their own age-depth models or without radiocarbon dates, the chronology given by their original authors has been assumed.

\section{FAGUS SYLVATICA RANGE MODELLING}

In order to gain a better understanding of the Holocene distribution of the Fagus sylvatica L. populations at their southern limit, we have integrated species distribution models (SDMs) to explain the palaeopalynological records collected throughout the SCS. F. sylvatica was modelled, 
Table 1

Number of sequences and radiocarbon dates of the Spanish Central System analyzed (For more details, see LóPEZ-SÁEZ \& al., 2013)

\begin{tabular}{lccccc}
\hline Mountain range & \multicolumn{3}{c}{ N. sequences by altitude (m asl) } & \multirow{2}{*}{$\begin{array}{c}\text { N. radiocarbon } \\
\text { dates }\end{array}$} \\
\cline { 2 - 5 } & $<1000$ & $1000-1500$ & $1500-2000$ & $>2000$ & 10 \\
Ayllón & - & 9 & 1 & 2 & 45 \\
Guadarrama & 2 & 11 & 16 & 5 & 61 \\
Gredos & 5 & 31 & 19 & - & 19 \\
Béjar & 2 & 5 & - & - & 14 \\
Francia & - & 4 & 5 & 1 & 1 \\
Gata & - & 1 & - & - & 150 \\
TOTAL & 9 & 61 & 41 & 8 & \\
\hline
\end{tabular}

first by calibrating the model for their current distributions in relation to the present climate, and then applying it to the Middle Holocene (6.000 cal yr BP) period to hindcast its past distribution.

\section{Climate data}

Current monthly temperature and precipitation data were downloaded from the WORLDCLIM database (HiJMAns \& al., 2005) at 30" resolution ( $\sim 1 \mathrm{~km}$ cell size at the equator). The same current variables and their paleoclimate reconstructions for the Mid- Holocene were downloaded from the PMIP2 database (BRACONNOT\& al., 2007) at the original resolution of $2.5^{\circ}$ cell size $(\sim 250 \mathrm{~km}$ cell size at the equator) for the models CCSM3 (ОтTоBLIESNER \& al., 2006) and MIROC3.2 (HARUMI \& EMORI, 2004). As changes in climate are assumed to be relatively stable over space (i.e. high spatial autocorrelation), a simple method has been used to downscale palaeo-reconstruction to the finer resolution of WORLDCLIM database (CCAFS CLIMATE, 2013). Climate anomaly (difference between current and palaeoclimate) was calculated at the coarser resolution and then statistically downscaled (i.e. spline interpolated) to 30 " resolution. Then, the anomalies were summed to the current data from the WORLDCLIM database.

After that, three variables have been derived, i.e. absolute minimum temperature, precipitation seasonality and water balance, from the monthly climate data representing cold tolerance, adaptation to summer drought and moisture requirements, respectively. These factors are well-known to affect plant species distribution and have been successfully used in SDMs (SKOv \& SvenNING, 2004). Absolute minimum temperature and water balance were calculated following SKOV \& SVENNING (2004); precipitation seasonality was calculated as the coefficient of variation of the monthly precipitations. The predictor variables had low correlations among them (Spearman correlation, $\left.r_{s}<0.65\right)$.

\section{FAGUS DISTRIBUTION DATA AND SPECIES DISTRIBUTION MODEL (SDM)}

The Forest Map of Spain (1:200000) was the cartographic base for estimating the current range of F. sylvatica (RUIZ DE LA TORRE, 1990). This species is currently restricted to the Iberian Northern Mountains, occupying mainly the Pyrenees and the Cantabrian Range, while its southernmost distribution reaches areas of the SCS. All the cells selected in the study area overlap in more than a 50 $\%$ with the distribution range of $F$. sylvatica drawn from the distribution map. 11190 pseudo-absence points (WISZ \& GUISAN, 2009) were randomly selected from all the cells in the study area (i.e. the Iberian Peninsula) where $F$. sylvatica had not been reported. This number of pseudo-absences is a high enough and equals the number of presences at the same time. In order to evaluate the model we randomly splitted the whole dataset, presences and pseudo-absences, into a $70 \%$ calibration set and a $30 \%$ validation set for testing purposes.

In order to model the potential distribution of F. sylvatica Generalized Linear Models (GLM) 
were performed, using the binomial family with a logit link function (GUISAN \& al., 2002). As F. sylvatica is widely distributed in central and northern Europe we used only linear terms of the predictor variables, aiming to represent the environmental limits of the species' climatic niche.

The previous model was used in order to hindcast the potential distribution of $F$. sylvatica during the Mid-Holocene, projecting it over the paleoclimate variables (NoGUÉs BRAVO, 2009). Then, we used the threshold that optimizes the sum of sensitivity and specificity of the training dataset to differentiate suitable areas vs. non-suitable areas (LiU \& al., 2005).

The model was evaluated using the Area Under the receiver operating characteristic Curve (AUC), a threshold independent measure, and True Skill Statistic (TSS), a threshold dependent measure. AUC is a statistic derived from a graphical plot that illustrates the model performance as a function of its discrimination threshold (PHILLIPS \& al., 2006). Despite its value varies between 0 and 1 , values below 0.5 are rare and its interpretation implies the model performs worse than random. Values of 0.5 mean that the model performs as good as a random guess, whereas 1 means a perfect discrimination power. TSS is a modification of the classical Kappa (AlLOUCHE \& al., 2006). Its value lies between -1 and 1 , where 0 is interpreted as a poor model and 1 as the perfect fit. Values below 0 are rare and, similarly to AUC, they mean a model performing worse than random.

\section{RESULTS AND DISCUSSION}

Current forest cover is considered to have been mainly shaped by climatic and human disturbances since the onset of the Holocene (JALUT \& al., 2009; HENNE \& al., 2013).

This period has generally been considered as a period of climate stability, compared to the rapid and intense variability of the Last Glacial. However, recent studies have revealed the existence of significant short-term decadal to centennial climate variability (e.g: MAYEWSKI \& al., 2004; WANNER \& al., 2008, 2011; JALUT \& al.,
2009). Among the diverse climatic factors, rainfall regime and specifically summer precipitation is considered the main determinant of Mediterranean holocene vegetation changes, specially on its first half (TzEDAKIS, 2007; COLOMBAROLI \& al., 2008; DORMOY \& al., 2009; JALUT \& al., 2009; FinSINGER \& al., 2010; BRAYSHAW \& al., 2011; MAGNY \& al., 2011, 2012; PEYRON \& al., 2011, 2012), affecting both the intensity and the recurrence of fire activity (Gil-Romera \& al., 2010; VANNiere \& al., 2011).

The Holocene has been proposed to be subdivided into three main periods: i) Early Holocene, between 11.700 and 8.200 cal yr BP, ii) Middle Holocene, between 8.200 and $4.200 \mathrm{cal} \mathrm{yr} \mathrm{BP,}$ and iii) Late Holocene, from $4.200 \mathrm{cal}$ yr BP to present (WALKER \& al., 2012). This subdivision fits well with Northern and Central European investigations (LJUNGQVIST, 2011), but the boundary between Early and Middle Holocene seems to be better established around 7.500-7.000 cal yr BP for the Mediterranean Region (PEYRON \& al., 2012; WALKER \& al., 2012).

In general terms a humid and temperate period could have been occurred throughout the Mediterranean Region on the Early Holocene (11.700$7.500 / 7.000$ cal yr BP), nuanced by a high seasonality, specially on its second half (JALUT \& al., 2009; DORMOY \& al., 2009; ABRANTES \& al., 2012; FinSINGER \& al., 2010; PEYRON \& al., 2011; BRAYSHAW \& al., 2011; VANNIERE \& al., 2011; MAGNY \& al., 2012) and interrupted by the cooling and drying $8.2 \mathrm{cal}$ kyr BP event (KOBASHI\& $a l .$, 2007; LÓPEZ-SÁEZ \& al., 2008; САCHO \& al., 2010).

The Middle Holocene (7.500/7.000-4.500/4.000 cal yr BP) was a more stable period, with less seasonality, wetter and probably cooler in the southern areas, with a contrasting pattern in areas north of $40^{\circ} \mathrm{N}$ (CHEDDADI \& al., 1997; BREWER \& al., 2009; CARRIÓN \& al., 2010; BARTLEIN \& al., 2011; PEYRON \& al., 2011; VANNIERE \& al., 2011; MAGNY \& al., 2012). It is also considered as a transition phase towards more arid conditions ending ca 5.500-4.500 cal yr BP (Dormoy \& al., 2009; JAlut \& al., 2009; PÉREz.OBiol \& al., 2011; MAGNY \& al., 2012). 
The Late Holocene (4.500/4.000 cal yr BP-present) shows an increasing aridification and seasonality, specially in southern areas (JALUT \& al., 2009; CARRIÓN \& al., 2010; GIL-ROMERA \& al., 2010; BRAYSHAW \& al., 2011; MAGNY \& al., 2012; PEYRON \& al., 2012), and also a general trend to cooler conditions which characterizes the Neoglatial period in the Northern Hemisphere (LJUNGQVIST, 2011; WANNER \& al., 2011). From 3.500/3.000 cal yr BP onwards temperatures and seasonality increase as full Mediterranean climatic conditions get installed, with an opposite pattern in northern areas (FRIGOLA \& al., 2007; JALUT \& al., 2009; MARTÍNEZ-CORTIZAS \& al., 2009; VANNIERE \& al., 2011). A humid period is recorded for the Iberian peninsula from 2.800 to 1.600 cal yr BP (Roman Humid Period), followed by a warm and arid period between ca. 1600 to 600 cal yr BP (Medieval Climate Anomaly) and a cold and wet phase between 600 and $150 \mathrm{cal}$ yr BP(Little Ice Age) (MARTín-PuERTAS \& al., 2010; NiETO-MoRENO \& al., 2011), before the settlement of Recent Warming (WANNER \& al., 2011).

On the other hand, first evidences of human impact are recorded ca. $5000 \mathrm{cal} \mathrm{yr} \mathrm{BP,} \mathrm{with} \mathrm{traces} \mathrm{of}$ agriculture in the Gredos and Guadarrama ranges (Franco MúGICA, 1995; LóPEZ-SÁEZ \& BlanCO GONZÁLEZ, 2005; FABIÁN, 2006; LÓPEZ-SÁEZ \& LÓPEZ-MERINO, 2007), although grazing activities were likely developed much earlier (e.g: FRANCO MúgicA, 1995; Ruiz ZaPATA, 2011; Abel SchaAd, 2012; Morales-Molino \& al., 2013). The Chalcolithic period ( $c a .5300-3900 \mathrm{cal} \mathrm{yr} \mathrm{BP}$ ) shows the first occurrences of large-scale deforestation and a more extensive land use, due to a progressive sedenterisation of the population (SHERRAT, 1981; VICENT, 1995, 1998). During the transition from the Late Chalcolithic to the onset of the Early Bronze Age (ca.4350- 3800 cal yr BP), coinciding with the $4.2 \mathrm{ka}$ cal yr BP dry event, the Chalcolithic agrarian landscape collapsed and became more pastoralist oriented, with a major decline in the number of settlements (FABIÁN \& al., 2006).

The onset of the Iron Age ( $c a .2850-2050 \mathrm{cal}$ yr BP) shows a sustained trend of rising population (FernándeZ-Posse, 1998; Blanco GonZÁLEZ, 2010), specially in high-altitude areas of central Iberia (BLANCO-GoNZÁLEZ, 2010), favoured by the onset of a climatic abrupt change to- wards wetter conditions $c a .2800 \mathrm{cal}$ yr BP (VAN GEEL \& al., 1998; BOND \& al., 2001; LÓPEZ-SÁEZ \& BLANCO-GONZÁLEZ, 2005; LÓPEZ-SÁEZ \& al., 2009). The human impact differentially affected the western and eastern sectors, being more pronounced on the latter (FRANCO MúgicA \& al., 2001; CURRÁs \& al., 2012). Roman times (ca. 2050-1500 cal yr BP) are characterized by largescale deforestations, as a consequence of the intensification of cropping, grazing, mining and forestry (ÁlVAREZ-SANCHÍs, 1997; SÁNCHEZ-PALENCIA \& al., 2003; BlanCO-GONZÁLEZ \& al., 2009). Only the Gredos range, in the central sector of the SCS, suffered a lesser impact due to its inaccessibility (ABEL SCHAAD, 2012).

The Middle Ages (1500-500 cal yr BP) is a period of increasing human pressure, with large clearance processes at high-altitudes, within a clear livestock-oriented pattern, although new lands were also brought into cultivation (BLANCO-GONZÁLEZ \& al., 2009; LÓPEZ-SÁEZ \& al., 2009B; ABEL SCHAAD, 2012). During the Feudal Period (850500 cal yr BP) the current high-altitude landscape of the SCS, with open grasslands and shrublands, is considered to have been developed due to the intensification of farming activities and livestock husbandry, the creation of La Mesta system of trashumant herds moving through the drove roads of these mountains, as well as the repeated use of fire (Franco Múgica, 1995; Abel SchaAd, 2012; ABEL SCHAAD \& LóPEZ-SÁEZ, 2013).

A further intensification of human pressure took place in the Early Modern Period (500-150 cal yr BP) marked, related to cropping, with a noteworthy broad expansion of olive groves, but also to livestock husbandry. High fire recurrence is reflected in alternating peaks of grasslands and scrublands in pollen diagrams. Finally, Late Modern Period (150-0 cal yr BP) brings major political changes which do not lighten human impact on most montane areas, but it is besides enhanced with an overall spread of forestry (ABEL SCHAAD, 2012; ABEL SCHAAD \& LÓPEZ-SÁEZ, 2013).

\section{Betula}

Two species are acknowledged in the Iberian Peninsula for this genus, Betula alba L. and $B$. 
pendula Roth. (CASTROviejo \& al., 1990). Birches are heliophilous species with a wide ecological range (COSTA TENORIO \& al., 1997). They have high dispersal ability thanks to their small wind-dispersed seeds and vegetative regeneration (DAVID \& BARBERO, 1995). These features imply a great plasticity to changes and a pioneer character, as revealed by their current relatively wide distribution area in the Iberian Peninsula (COSTA TENORIO \& al., 1997) and recent findings in the western sector of the SCS (PULIDO \& al., 2007). Birches are defined as boreal species (SVENNING \& al., 2008; SANZ\& al., 2011) widely distributed in high latitudes. In the Iberian Peninsula it makes up forests in the Eurosiberian Region, where reaches its optimum, taking up the timberline. It also behaves, due to its heliophilous nature, as a successional phase from other disturbed forests like high-mountain pine, deciduous oak or fir ones. Southwards, where summer drought limits its presence, it uses to grow in riparian or in highmoisture locations like peaty environments (Costa Tenorio \& al., 1997; SAnz\& al., 2011).

Pollen records of the SCS show a regular occurrence of Betula, displaying its distinct mentioned settings. Its rapid response to disturbances (DAVID \& BARBERO, 1995) makes birch a good indicator of landscape changes, both climate and human-induced (JANSSEN \& WOLDRINGH, 1981). Moreover, its affinity for hygrophilous environments in Mediterranean environments provides an unquestionable local trace. This trait could mask its regional spread, so that it is sometimes excluded from the pollen sum (VAN DER KNAAP \& VAn Der LeEuwen, 1995). Nonetheless, a broad outline of its Holocene evolution in the studied area has been drawn up, comparing it among the most representative pollen records (Figure 2).

The Early Holocene (11.700-7.500/7.000 cal yr BP) is characterized by the dominance of birch forests in the western sector, Francia and Béjar ranges, favored by the humid and temperate climate. Minima in the curve of El Maíllo (MoRALES-Molino \& al., 2013) are related to fire events, at the same time linked to climate, with a noteworthy seasonality (JALUT \& al., 2009; DoRMOY \& al., 2009; VANNIERE \& al., 2011; CONNOR \& al., 2012). It is nevertheless remarkable the recovery of Betula levels after every fire episode, highlighting its resilience against disturbances. The relative stability showed in El Trampal (Béjar range) (ATIENZA BALLANO, 1993) could be explained by the greater rainfall regime at higher altitudes. Eastwards, birch forests show a limited extent, specially in the Guadarrama range, where Pinus sylvestris forests are better adapted to the more continental climatic conditions (FRANCO MúGICA \& al., 1998).

A distinct contrast is observed throughout the Middle Holocene (7.500/7.000-4.500/4.000 cal yr BP) between western and eastern sectors. Wetter and cooler climatic conditions (CHEDDADI \& al., 1997; BREWER \& al., 2009; BARTLEIN \& al., 2011; VANNIERE \& al., 2011; MAGNY \& al., 2012) could be the reason of the retreat of birch forests in the Francia and Béjar ranges, in the more Atlantic-influenced western sector, and their slight progress in the Gredos (Franco MúGICA, 2009) and Guadarrama ranges, following altitudinal shifts. But these trends could have most likely been triggered

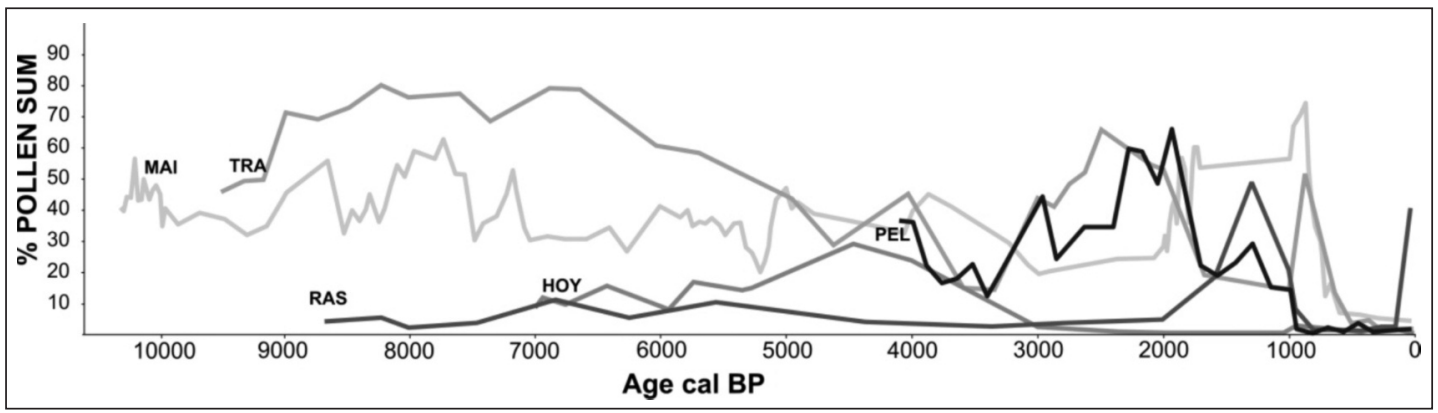

Figure 2. - Representative Holocene pollen records of Betula in the SCS. MAI, El Maíllo (Francia); TRA, Garganta del Trampal (Béjar); HOY, Hoyos del Espino (Gredos); RAS, Rascafría (Guadarrama); PEL, Pelagallinas (Ayllón). 
by the first human activities in the area, promoting the spread of grasslands in the Béjar range and, to a lesser extent, in the Gredos and Guadarrama ranges, as well as the decline of pinewoods and the subsequent extent of heathlands in the Francia range.

Human impact becomes more apparent in the transition to the Late Holocene $(4.500 / 4.000 \mathrm{cal}$ yr BP-present). Diverse responses of Betula can be inferred from the pollen records. In the Francia range the increasing fire incidence affects basically pinewoods, allowing the spread of grasslands and a minor extent of birch forests, which would colonize the resulting clearings. Pasturelands would have also result from clearing in the Béjar range, here mostly concerning the dominant birch forests, whereas pinewoods declined in the Gredos range. The onset of the $4.2 \mathrm{ka}$ cal yr BP cold event (JALUT \& al., 2000, 2009; LóPEZ SÁEZ \& al., 2008; MAGNY \& al., 2009) allows a new and synchronous climate-mediated spread of birch forests, also benefited from a decrease of human pressure.

A synchronous decline of birch forests occurred after this climatic event, related to an arid phase (MAYEWSKI \& al., 2004; JALUT \& al., 2009) but also to the intensification of grazing activities which characterizes the Early Bronze Age (FABIÁN \& al., 2006) in the Mediterranean Region (VANNIERE \& al., 2011). The growing human pressure is only absent in the Gredos and Ayllón ranges, where pinewoods recover against birch forests thanks to the more continental climatic conditions of this phase.

From this period onwards the evolution of birch forests is mostly mediated by human impact (TURNer \& al., 2008; Colombaroli \& al., 2010), although climate still keeps a relevant role. Livestock husbandry becomes the main activity and the need of pasturelands will progressively lead these communities to fragmentation and isolation. The recurrence of disturbances, with fire and grazing as the leading drivers (HENNE \& al., 2013), is clearly displayed in the pollen records. Birch primarily colonizes deforested areas but above a certain threshold it cannot recover its former extension. This threshold seems to have been crossed very recently, ca 500 cal yr BP, with the distinctive and widespread livestock activities of Late Medieval and Early Modern periods (FRANCO MúGICA \& al., 1998; Franco MúGiCA, 2009; Abel SchaAd, 2012; LóPEZ-SÁEz \& al., 2013) The rapid response to disturbances is particularly apparent in Rascafría (Guadarrama range), which shows a sharp increase of this species coinciding with the clearance of pinewoods, followed by an acute fall due to the spread of grasslands. The same pattern is observed in Francia, Béjar and Ayllón ranges, where significant recoveries are shown, allways followed by a marked decline. This drop is earlier recorded in the Gredos range, where the presence of Betula is very scarce since ca. $3000 \mathrm{cal} \mathrm{yr} \mathrm{BP.}$

Pollen records illustrate the great ecological flexibility of Betula. Altitudinal shifts have been its main response to climate changes. Its recent isolation close to high-mountain streams in northfacing slopes (SANZ \& al., 2011) has been the consequence, above all, of human pressure through fire and grazing, although increasing seasonality and temperatures may have also played a significant role.

\section{TAXUS}

Taxus baccata L. is a dioecious widespread species in Europe but currently forming small and isolated populations, specially in the Mediterranean basin (COSTA TENORIO \& al., 1997; GARCÍA \& al., 2000; SANZ \& al., 2009; DubreuIL \& al., 2010). In the Iberian Peninsula its abundance increases northwards, where it can be found from the sea level, while it becomes sparser southwards, usually growing over $1000 \mathrm{~m}$ asl (COSTA TENORIO \& al., 1997). It withstands disturbances, with strategies such as a slow growth, an outstanding longevity, a marked shade tolerance, although it can also develop well on sunlight in northern latitudes, and the adaptation to a wide range of soils (THOMAS \& POLWART, 2003; ZAREK, 2009). It requires a certain degree of soil moisture, albeit yew is considered a drought-tolerant species among cool temperate trees (BRZEZIECKI \& KIENAST, 1994; THOMAS \& POLWART, 2003; Valladares \& NiInemets, 2008; Perrin $\&$ Mitchell, 2013). Therefore, yew grows close to watercourses on north-facing slopes in the sou- 
thern margins of its range (PULIDO \& al., 2007; SANZ\& al., 2009; LiNARES, 2013).

It has also great dispersal ability thanks to its wind-mediated pollen and bird-mediated seed removal (GARCÍA \& al., 2000; BHAGWAT \& WILLIS, 2008; DuBREUIL\& al., 2010; LINARES, 2013). However, the influence of the successive glacial cycles as well as the intensity of human-induced disturbances, have progressively fragmented its populations up to the current decline (HILFIKER \& al., 2004; GONZÁLEZ-MARTíNEZ \& al., 2010).

Pollen records demonstrate its presence throughout the Pleistocene in the northern, central and southern Iberian Peninsula (GONZÁLEZ-MARTÍNEZ \& al., 2010), but its percentages use to be always low, displaying a scattered distribution within surrounding vegetation. This long-term fragmentation of yew populations has triggered a strong divergence between populations, likely related to its poor regeneration, defined by very few successful recruitment events (HILFIKER \& al., 2004; GONZÁLEZMARTíneZ \& al., 2010; LinARES, 2013). These events could have been more common during the Middle Holocene (7.500/7.000-4.500/4.000 cal yr $\mathrm{BP})$, with wet climatic conditions and little seasonality (CHEDDADI \& al., 1997; BREWER \& al., 2009;
VANNIERE \& al., 2011; MAGNY \& al., 2012), as revealed by the significant percentages appearing in the Estrela range (VAN DER KNAAP \& VAN LEEUWEN, 1995). From this period onwards, yew populations have decreased in number, connectivity and size in many parts of Europe due particularly to increasing human pressure (THOMAS \& POLWART, 2003; HiLFIKER \& al., 2004; LiNARES, 2013).

Figure 3 shows the current distribution of Taxus baccata in the SCS and the comparatively sparse yew reports on pollen records. Yew pollen can be wind-dispersed over a number of kilometers (THOMAS \& POLWART, 2003), but its pollen productivity seems to be limited (NORYSKIEWICZ, 2003), so even low percentages in pollen diagrams would point to the local presence of yew. Hence, a wider distribution could be expected in spite of the scarcity of pollen deposits. In addition, its pollen always appears sporadically, pointing to the above fragmented pattern throughout the Holocene.

Only the Garganta del Villar deposit (LóPEZSÁEZ \& al., 2013) reports a significant amount of Taxus pollen $(>2 \%)$. This record is dated in the Early Holocene (ca. 9300-8450 cal yr BP), which may express a wider extent of this species at this time. All other records reflect the occasional pre-

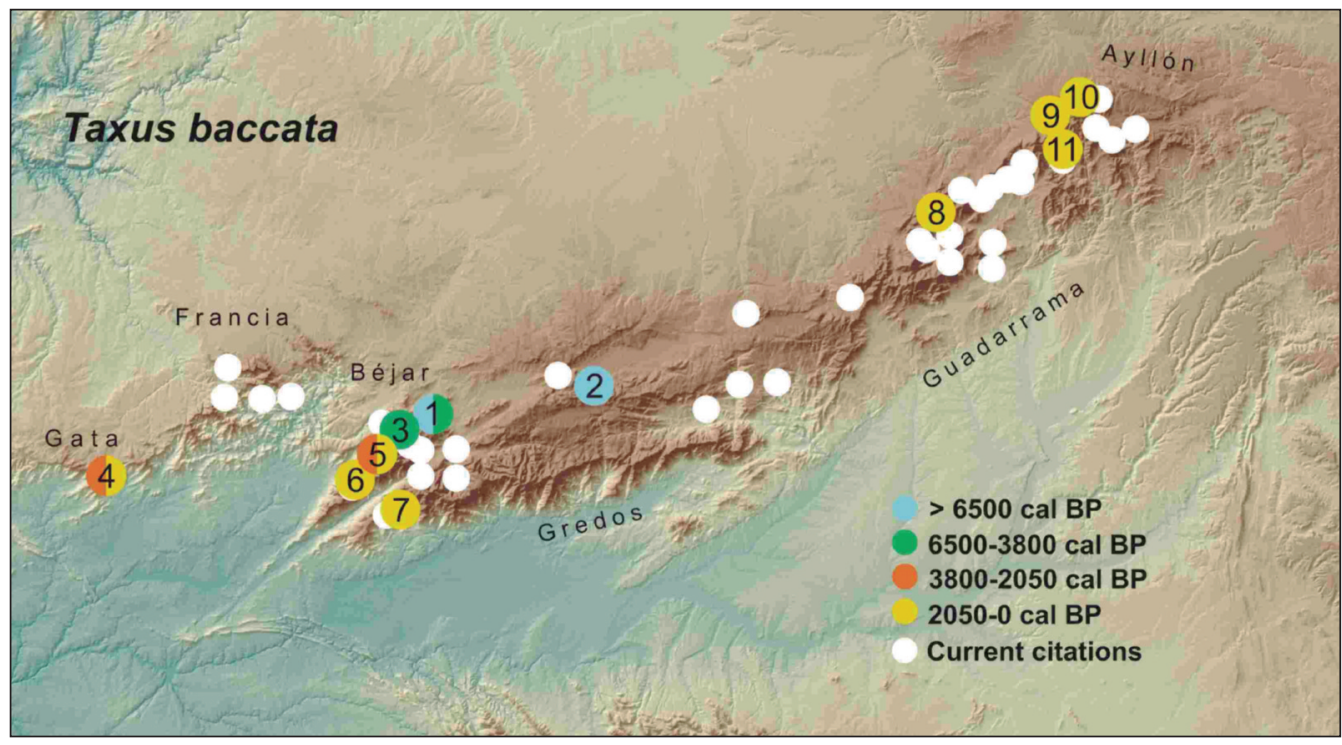

Figure 3. - Holocene pollen records of Taxus in the SCS. 1. Garganta del Trampal; 2. Garganta del Villar; 3. Dehesa de Navamuño; 4. Puerto de Santa Clara; 5. Peña Negra; 6. Jerte; 7. La Panera; 8. Lagunillas; 9. Hontanares; 10. Martín Muñoz de Ayllón; 11. San Benito. 
sence of yew, from Middle Holocene (7.500/7.0004.500/4.000 cal yr BP) in the Béjar range (ATIENZA BALlANO, 1993) to Late Holocene in the Gata (ABEL SCHAAD \& al., 2009a), Béjar (ABEL-SCHAAD \& LÓPEZ-SÁEZ, 2013), Gredos (ATIENZA BALLANO, 1993; ABEl SCHAAD \& al., 2009b), Guadarrama (Ruiz del Castillo, 1993) and Ayllón (Ruiz DEL CASTILlO, 1993) ranges.

Climate has been marked as the main driver of yew distribution (SVENNING \& al., 2008), with water availability performing the leading role on southern populations (SANZ \& al., 2009; LINARES, 2013). Responses would have mostly consisted in altitudinal shifts (HewITT, 2001). From Middle Holocene onwards forestry practices, grazing and, specially, fire recurrence would have led some of them to extinction, as shown in the Gata range, or to isolated and almost inaccessible enclaves (SANZ \& al., 2009; LiNARES, 2013).

\section{FAGUS}

Beech (Fagus sylvatica L.) is a deciduous broadleaf species with an almost continuous distribution in the Atlantic Europe, forming monospecific forests (Costa TENORIO \& al., 1997), an outstanding feature among temperate trees (LEUSCHNER \& al., 2006). It is remarkably tolerant to a variety of climatic and hydrological factors, growing from very acid to calcareous soils with annual rainfall between 550 and $2000 \mathrm{~mm}$ throughout its distribution area, and requiring rather moist summers and mild winters. In addition, its shade tolerance gives this species an advantage over other competing trees, thus becoming the most successful forest species in Central Europe (LEUSCHNER \& al., 2006; Von WüHLISCH, 2008).

The Iberian distribution is essentially centered in the Cantabro-Pirenean Mountains, decreasing to the western cantabrian area. The southernmost populations correspond to isolated enclaves in the SCS (Costa TenORIO \& al., 2007). Drought is the most limiting factor for $F$. sylvatica populations at its southern range (GRANIER \& al., 2000; JUMP \& al., 2006; TINNER \& LOTTER, 2006; BRADSHAW $\& a l ., 2010)$ as well as pronounced continental climates and very sandy or waterlogged soils (Chala, 2010; Bradshaw \& al., 2010).

Beech citations (Figure 4) are more abundant in the eastern sector of the SCS, specially in the

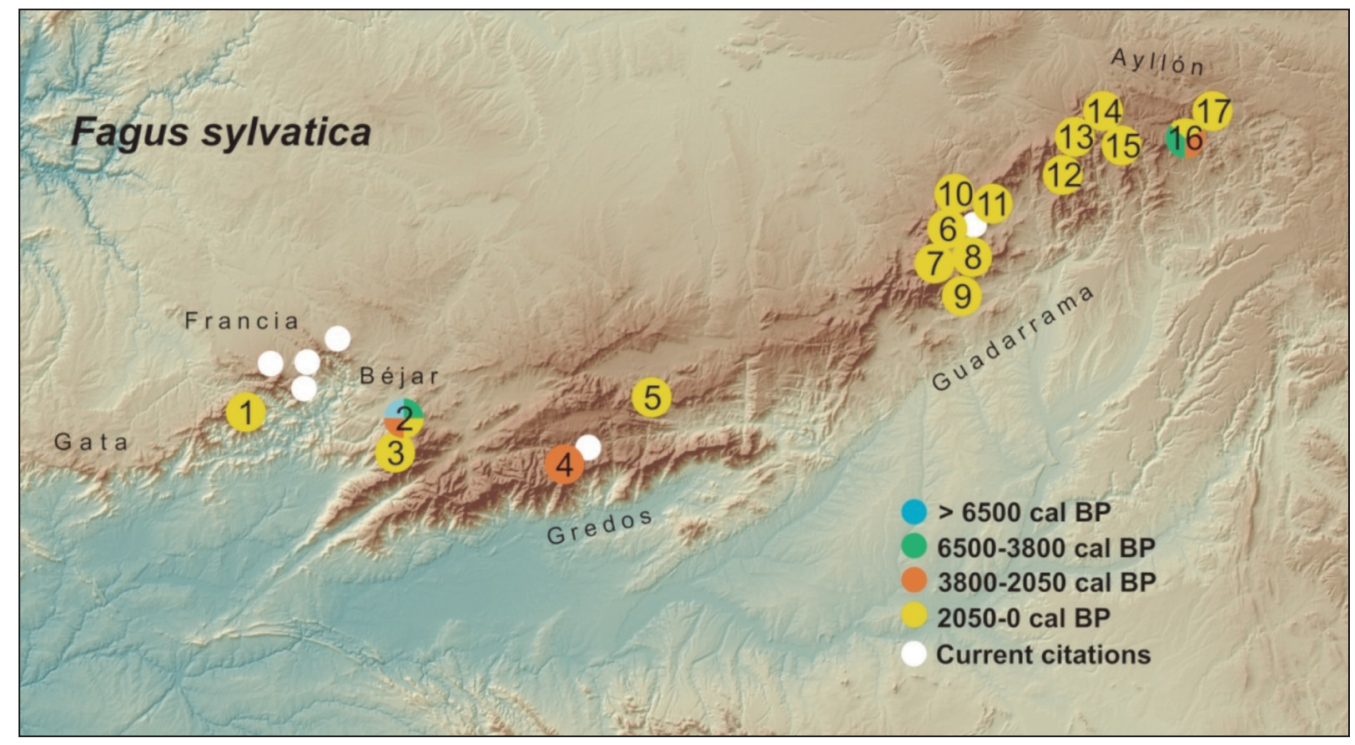

Figure 4. - Holocene pollen records of Fagus in the SCS. 1. La Meseguera; 2. Cuerpo de Hombre; 3. Peña Negra; 4. Los Conventos; 5. Navalguijo; 6. Rascafría; 7. Cerro Genciana; 8. Espartal; 9. Puerto de Canencia; 10. Hoyos de Pinilla; 11. Peñas Crecientes; 12. Hayedo de Montejo; 13. Pico del Lobo; 14. Puerto de la Quesera; 15. Tejera Negra; 16. Pelagallinas; 17. Somolinos. 
Ayllón range (RIVAS-MARTíNEZ, 1962, 1963; MAYOR, 1965; HERNÁNDEZ BERMEJO \& SAINZ Ollero, 1984; ANTHOS, 2013). They decrease westwards, with sparse ones in the Gredos (AMOR \& al., 1993), Francia (CASASECA, 1975; FERNÁNDEZ DíEZ, 1976) or Gata (PULIDO, pers. com.) ranges, apart from older citations, without confirmation, in the Gredos and Gata ranges (LERESCHE \& LEVIER, 1880; LAGUNA, 1883; WILLKOMM, 1896; RIVAS MATEOS, 1898; CUATRECASAS, 1932).

$F$. sylvatica forests have experienced a very recent spread in Europe, which had its origin in the Middle Holocene (MAGRI \& al., 2006; VALSECCHI \& al., 2008; MAGRI, 2008) starting from multiple northern glacial refugia. The Iberian Peninsula refugia have also been detected in northwestern areas (RAMIL-REGO \& al., 2000), Iberian System (LÓPEZ-MERINo \& al., 2008) as well as Cantabrian massifs and Pyrenees (MARTíneZ ATIENZA \& MORLA JUARISTI, 1992). Although the above refugia do not seem to have contributed to the beech spreading along Central Europe (BRUS, 2010), the Iberian isolated populations would have allowed the local distribution across mountain ranges acting as passageways while large sedimentary plains acted as barriers (MAGRI \& al., 2006)

The SCS pollen records (Figure 4) provide the oldest presence of $F$. sylvatica ca. 5800 cal yr BP (RUIZ ZAPATA \& al., 2011) in the Bejar range. It is also detected in Ayllón range (from the base of Pelagallinas deposit) around 4100 cal yr BP (Franco Múgica \& al., 2001), in the Gredos range from 3000 cal yr BP (RUIZ ZAPATA \& ACASO 1981; FrANCO MúGICA, 1995) and more recently in the Francia (ABEL SCHAAD, 2012), Béjar (ABEL-SCHAAD \& LÓPEZ-SÁEZ, 2013), Guadarrama (VÁzQUEZ, 1992; GIL GARCíA, 1992; Franco MúGICA \& al., 1998) and Ayllón (GIL GARCÍA, 1992; CuRRÁs \& al., 2012) ranges. It has not been yet recorded in the westernmost sector, i.e. in the Gata range nor in the Estrela range. The scarcity of sequences covering longer chronological periods (RUIZ-ZAPATA \& al., 1998) prevents the detection of older appearances which could shed light on the possible establishment of local glacial refugia. In addition, both the poor pollen production (ANDERSEN, 1970; BJUNE \& al., 2013) and its limited pollen dispersal capacity (MOORE \& al., 1991) hinder its appearance in fossil records (JACOBSON \& BRADSHAW, 1981; CONEDERA \& al., 2006). According to POSKA \& PIDEK (2010) an important reduction of pollen grains is already noticeable at ca $300 \mathrm{~m}$ from the closest stand and it almost disappears beyond $1800 \mathrm{~m}$.

Most records provide a sporadic presence of beech, suggesting a pattern of isolated populations, which fits well with its seed dispersal, mainly by birds (VALSECCHI \& al., 2008), but also hampers detecting potential expansion routes from East to West according to MARTínEZ Atienza \& Morla Juaristi (1992) and Costa TENORIO \& al. (1997). In addition, first occurrences in the Bejar range (Cuerpo de Hombre; RuIz ZAPATA \& al., 2011), or in Ayllón range (Pelagallinas; FRANCO MúGICA \& al., 2001), are older than recent expansion of beech in the Iberian System (LóPez-Merino \& al., 2008). Consequently, they can be proposed as refuge areas. Probably, these populations would have consisted of small widespread isolated stands and hence their pollen signal would be rather inconspicuous (GIESECKE \& al., 2007; MAGRI, 2008). This conclusion is supported by the current distribution of beech forests understorey species in the SCS, which is also a reasonable indicator (WILLNER \& al., 2009). Moreover, current potential distribution models (SÁnchez Palomares \& al., 2004) show wide potential areas for beech forests in the SCS.

In order to identify territories likely occupied by this species at the Middle Holocene and to clarify whether its distribution could be wider along the SCS, we used Species Distribution Modelling (SDM) (Figure 5). The accuracy measures for the distribution model of $F$. sylvatica are shown in Table 2. This model based on the environmental limitations of the species' climatic niche (Figure 6) provides more evidences about the beech potential distribution $c a .6000 \mathrm{cal}$ yr BP, suggesting suitable climatic areas for establisment. According to response curves (Figure 6) the water availability variables (Pse: precipitation seasonality; and Wbal: water balance) show the strongest discriminant power. Therefore, gradual climate aridity could have reduced the habitat availability 


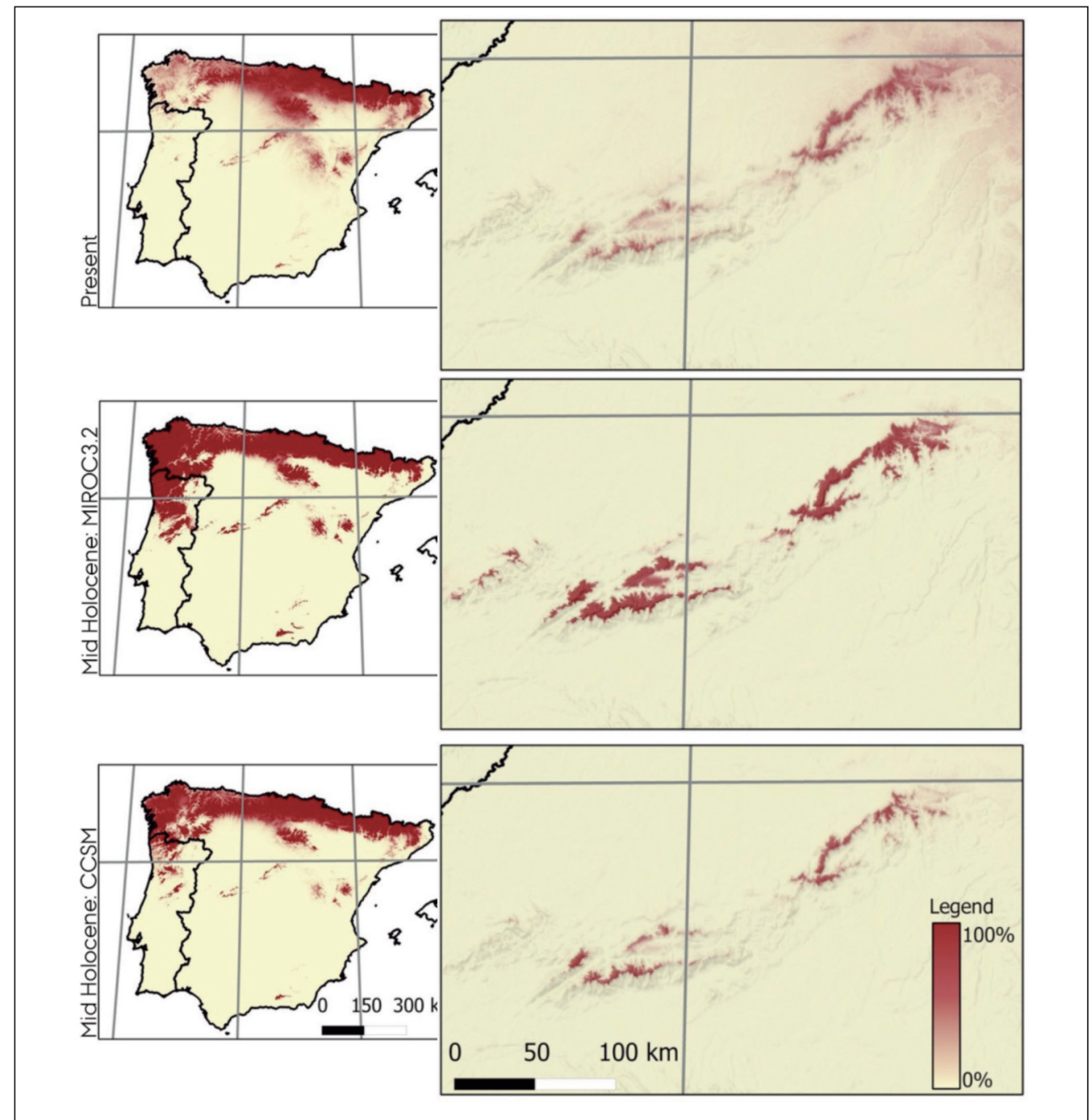

Figure 5. - Potential distribution of Fagus sylvatica in the Iberian Peninsula. Present and Mid-Holocene.

for beech. Additionally, competition with other forest species such as Quercus robur or $Q$. pyrenaica in the western sector, and Pinus sylvestris in the eastern ones, likely hampered the beech spread from the original isolated populations.
Also remarkable is the appearance of beech pollen in many records following clearance events, as shown, for example, in Peña Negra (ABELSCHAAD \& LÓPEZ-SÁEZ, 2013), which supports the hypothesis of its Holocene expansion favoured by

Table 2

Accuracy measures for the distribution model of Fagus sylvatica

\begin{tabular}{lcccccc}
\hline & $N^{\circ}$ Presence & $N^{\circ}$ Absence & Threshold & Prevalence & $\begin{array}{c}\text { AUC } \\
{[0: 1]}\end{array}$ & $\begin{array}{c}\text { TSS } \\
{[-1: 1]}\end{array}$ \\
\hline Train & 8400 & 8533 & 0.431 & 0.491 & 0.962 & 0.868 \\
Test & 3501 & 3377 & 0.431 & 0.509 & 0.957 & 0.861 \\
\hline
\end{tabular}




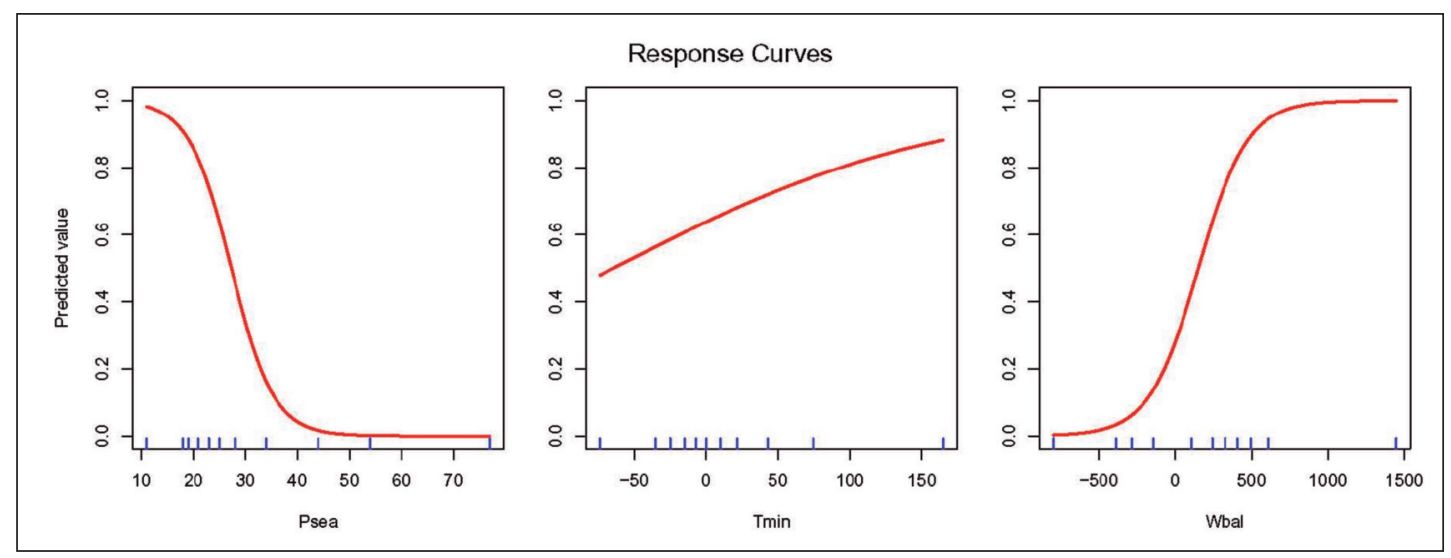

Figure 6. - Response curves of Fagus sylvatica distribution model to each of the variables used to build the model. Tmin, absolute minimum temperature; Psea, precipitation seasonality; and Wbal, water balance.

human activities (e.g. VAN DER KNAAP \& al., 2005; LÓPEZ-MERINO \& al., 2008; PELACHS \& al., 2009; BJUNE \& al., 2013) in spite of the underlying effect of climate (TINNER \& LOTTER, 2006; GIESECKE \& al., 2007; VALSECCHI \& al., 2008; BRADSHAW \& al., 2010). It should be remembered the leading role featured by moisture availability in these southernmost limits (JUMP \& al., 2006). Anyway, increasing seasonality and a more intense human pressure would have directly led many of these relict populations to extinction, but also indirectly, giving advantage to more adapted competing species like Quercus pyrenaica, which dominate in current forest communities (SÁNCHEZ Palomares \& al., 2004). However, most of the sites in which $F$. sylvatica is currently extinct show a great persistence until the last 200 years, likely linked to adaptive responses to climatic and anthropogenic disturbances (KRAMER \& al., 2010).

\section{CARPINUS}

Carpinus betulus $\mathrm{L}$. is a tree species within the Betulaceae, virtually extinct in the Iberian Peninsula, with only remnant populations in the Bidasoa valley, in Navarra and Guipúzcoa (AizPURU \& CATALÁN, 1984; CASTROVIEJO \& al., 1990). However its presence has been noted in many pollen records throughout the Pleistocene, both in the north and the south of the Iberian Peninsula (GRIvet \& Petit 2003; Postigo \& al., 2008, 2010), though it shows a dramatic decline since the Middle Holocene (Pearman \& al., 2008).

Carpinus betulus has a narrow ecological range (PINTO \& GEGOUT, 2005). It requires fertile and deep soils, so it uses to grow in low and flat areas (AizPURU \& CATALÁN, 1984; MAGYARI, 2002). On the other hand, it is a drought-intolerant species and does not withstand well winter cold, as it is considered a termophilous species (Postigo \& al., 2008). Its seed dispersal ability is limited, specifically within other forests, such as beech or oak ones (PETIT \& al., 2003; GRIVET \& Petit, 2003; Bhagwat \& Willis, 2008).

Glacial refugia for this tree seems to have been located in the southern European peninsulas (Bhagwat \& Willis, 2008; Svenning \& al., 2008), but the postglacial colonization would have been led from Balkan populations, while Iberian ones would have gone extinct (GRIVET \& Petit 2003; Pearman \& al., 2008).

A broad spread of Carpinus has been reported in Central Europe around $4300 \mathrm{cal}$ yr BP (PoKORNY, 2005), following a similar pattern to beech, favoured by a moderate human pressure (VAN DER KNAAP \& al., 2005; BJUNE \& al., 2013). However, in the Canary Islands its disappearance coincides with an increase in fire recurrence around $2000 \mathrm{cal}$ yr BP (De NASCimento \& al., 2008; Postigo \& al., 2010). The decline of Carpinus in the Iberian Peninsula is considered to have been the consequence of a synergic effect (BROOK \& al., 2008) among an increasing seasonality, human pressure and the 
competition with other trees, like beech, hazel or different oaks (Postigo \& al., 2010).

In the SCS (Figure 7) its presence is detected in the Early Holocene in the Béjar range (ATIENZA BALLANO, 1993), and it disappeared during the transition to the Late Holocene, around $4000 \mathrm{cal}$ yr BP. It is also detected more recently in the Ayllón range (GIL GARCÍA, 1992) in medieval times. These are the only occurrences throughout the massif, in addition to the ones reported in the Estrela range (VAN DER BRINK \& JANSSEN, 1985) between 6000 and $5000 \mathrm{cal} \mathrm{yr} \mathrm{BP}$. Its decline in the western sector could be related both to climatic and anthropogenic reasons, as it coincides with a period of increasing aridity and seasonality, but also of increasing human population. Most populations would go extinct, unable to compete with better-adapted species. Its last trace, recorded in the eastern sector $c a .1000 \mathrm{cal}$ yr BP, would suggest the persistence of very scattered populations.

\section{TILIA}

The genus Tilia includes two species currently distributed in the Iberian Peninsula, namely Tilia cordata and T. platyphyllos. The former shows an area restricted to the northern regions, while $T$. platyphyllos keeps its southernmost populations in the southernmost mountains of Iberian Range (Costa TenORIO \& al., 1997; ANON, 2013), with some isolated stands in several enclaves further south. Both of them have wide distribution areas in Europe, specially T. cordata. In the Iberian Peninsula they grow within mixed forests, in which they rarely become dominant (COSTA TENORIO \& al., 1997).

Tilia species are defined as shade-tolerant, but to a lesser extent than Fagus or Carpinus (PIGGOT, 1991; SvenNing \& al., 2008). They require wet and temperate climates with rich and fresh soils, preferably calcareous (RADOGLOU \& al., 2008). Summer drought is its main limiting factor, although T.platyphyllos withstands it better than $T$. cordata (SvejgaARD Jensen, 2003). Its capability to grow on watterlogged soils or areas with a high groundwater level, allows them to survive along watercourses in regions with a pronounced summer drought (COSTA TENORIO \& al., 1997).

Both species reproduce more frequently vegetatively than sexually, improving their dispersal ability (Piggot \& Huntley, 1981; SvejgaARD JENSEN, 2003). They are mainly entomophilous, with a minor role of wind pollination (FAEGRI \& IVERSEN, 1989). This entails a low pollen disper-

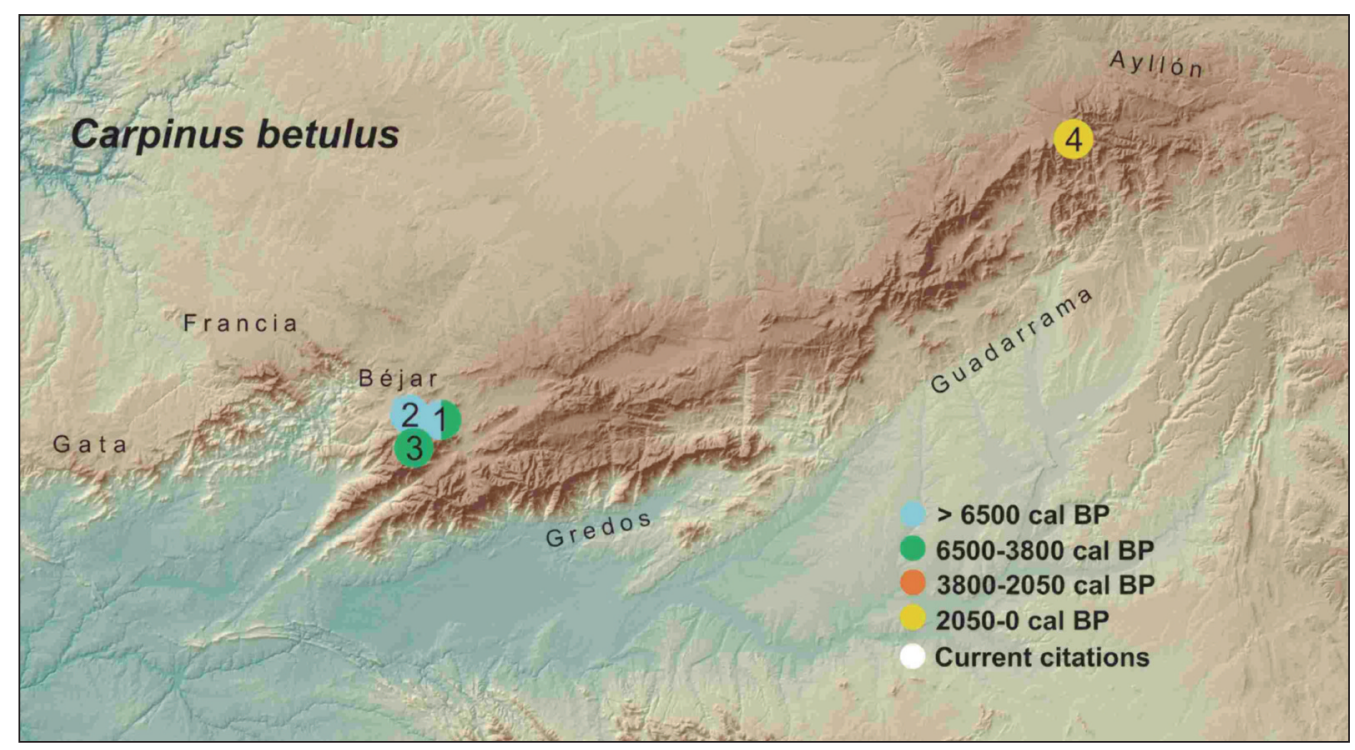

Figure 7.- Holocene pollen records of Carpinus in the SCS. 1, Garganta del Trampal; 2, La Covatilla; 3, Navamuño; 4, Pico del Lobo. 
sal (KreBs \& al., 2004; Conedera \& al., 2006) resulting in a significant under-representation in most pollen spectra (ANDERSEN, 1970).

Current citations in the SCS (Figure 8) are very sparse. Tilia platyphyllos appears in the Gata, Béjar, Gredos, Guadarrama and Ayllón ranges, while $T$. cordata is only cited in the Gredos range (SARDinero, 2004; ANTHOS, 2013).

Tilia pollen has been identified during glacial cycles in several sites in the Cantabrian coast and the Levant (GARCÍA-AMORENA \& al., 2007; CARRIÓN \& al., 2007). It has been also sporadically detected in many Holocene records across the Iberian Peninsula, more frequently in its northern half. Glacial refugia would have sheltered Tilia populations in Iberian coastal and mountain areas (BREWER \& al., 2002; BHAGWAT \& WILLIS, 2008; SvENNING \& al., 2008). In addition, various refugial areas have been located further north, in Central Europe, from which Tilia would have spread in the Early Holocene (WILLIS \& al., 2000; FINESCHI \& al., 2003). From the Middle Holocene onwards a steady decline of Tilia populations is detected throughout Europe, related specifically to the increasing intensity of human activities (GRANT \& al., 2011).
The oldest Tilia pollen record (Figure 8) in the SCS is located in the Gredos range (Puerto de Chía; ANDRADE \& al., 1996) ca. 2245 cal yr BP. It appears ca. 1500 cal yr BP in the Béjar (ATIENZA BALLANO, 1993) and Guadarrama (RUIZ DEL CASTILLO, 1993; GIL-GARCÍA \& al., 1996) ranges, and around 1000 cal yr BP in the Francia (ABEL SchaAD, 2012) and Ayllón (GIL GARCíA, 1992) ranges. More recent occurrences are detected in the Guadarrama (RUIZ del Castillo, 1993; Gil-García \& al., 1996; RuIZ-ZAPATA \& al. 2009) and Ayllón (GIL GARCía, 1992). All of them occur sporadically, likely related to the low signal left by Tilia on pollen records and also to the scattered distribution of its stands. But the most striking point is its absence before Iron Age, as it appears ca. $2800 \mathrm{cal} \mathrm{yr} \mathrm{BP}$ in the Estrela range (JANSSEN \& WOLDRINGH, 1981).

These data may suggest a recent human-mediated introduction, but older occurrences in the Iberian Peninsula and the lack of historical records, could point to altitudinal shifts (JUMP \& al., 2009; Willis AND MaCDONALD, 2011) of ancient populations previously located on valleys, which would have brought them closer to the pollen deposits. The overall decline of its populations in

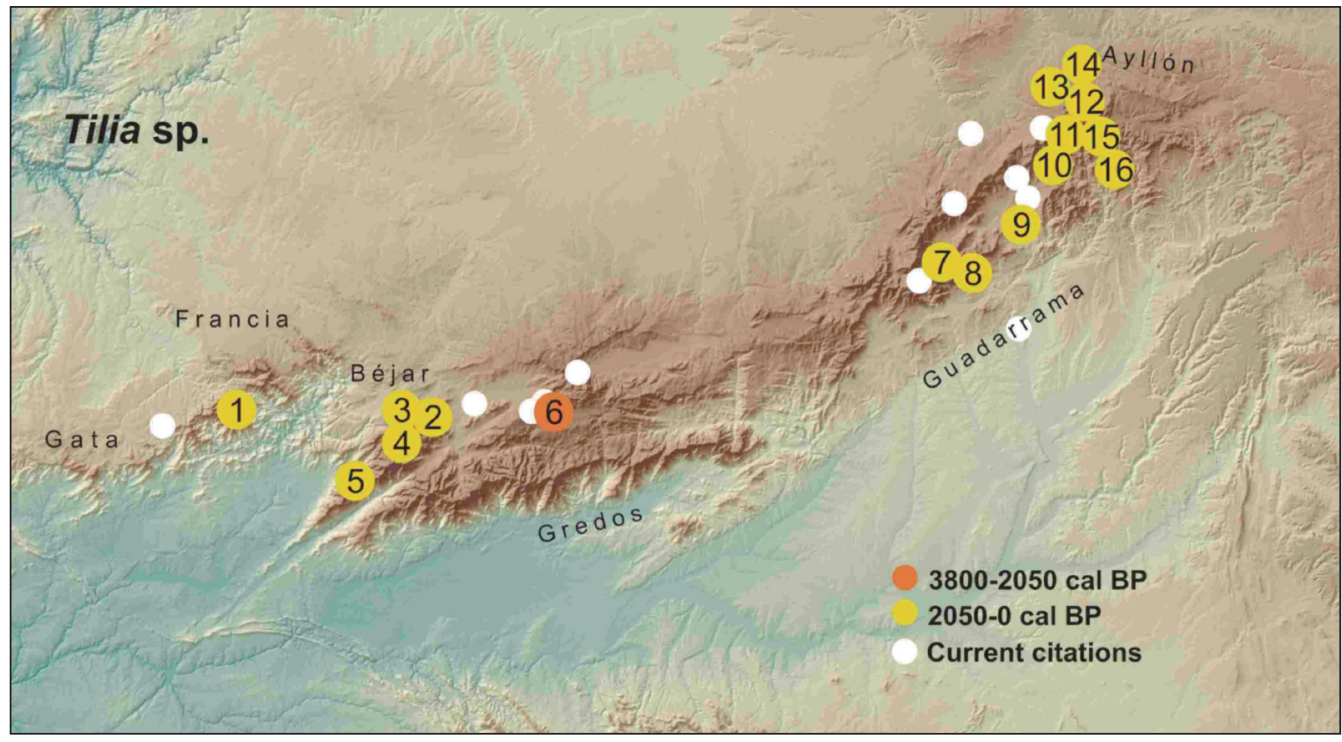

Figure 8. - Holocene pollen records of Tilia in the SCS. 1. La Meseguera; 2. Garganta del Trampal; 3. La Covatilla; 4. Navamuño; 5. Jerte; 6. Puerto de Chía; 7. Peña de La Morcuera; 8.Puerto de la Morcuera; 9. Collado de El Berrueco; 10. Hayedo de Montejo; 11. Pico del Lobo; 12. San Benito; 13. Hontanares; 14. Martín Muñoz de Ayllón; 15. Puerto de la Quesera; 16. Tejera Negra. 
Europe would support this hypothesis. Nonetheless, a recent introduction by humans should not be totally discarded, in virtue of its medicinal properties or the quality of its wood.

\section{CONCLUDING REMARKS}

Pollen analyses performed in the SCS support the ancient origin and show the responses to both climatic and anthropogenic disturbances of some relict tree species throughout the Holocene. They also highlight the exceptional value of current isolated enclaves which sustain many of their southernmost populations, to assess the future evolution of the remnant ones.

Persistence has not always been the final result among the species analyzed in this paper. Hornbeam (Carpinus betulus) is already extinct in almost all the Iberian Peninsula, likely due to its narrow ecological range and low dispersal abilities, although it overcame the glacial cycles reaching the Middle Holocene. The increasing summer drought and the recurrence of human-induced disturbances would have prevented it to compete with other better-adapted species.

Few isolated stands of lime trees (Tilia spp.) persist currently in the SCS. It seems that they never were abundant in this region, as their pollen only appears during the last three millenia, showing either altitudinal shifts in response to disturbances or, less likely, a human-mediated introduction.

Beech (Fagus sylvatica) still keeps significant populations in the eastern sector of the SCS and very scattered citations westwards. The origin of these populations, usually attributed to a Late Holocene spread from more northern areas, could be seriously questioned by means of pollen records, providing earlier appearances than its hypothetical expansion. Species Distribution Modelling supports this theory, showing wide potential areas for beech in the Middle Holocene. Western populations would have gone virtually extinct in the last centuries, while the eastern ones have persisted over time.

Yew (Taxus baccata) does not seem to have formed wide forests during the Holocene in the SCS, despite its widespread distribution. Anyway, it has undergone a significant decline since Mid- dle Holocene. Its populations have progressively become confined close to watercourses in northfacing slopes thanks to its longevity and by altitudinal shifts.

Birch (Betula spp.), like yew, has persisted until present day in the SCS, but it dominated forest vegetation, specially in the westernmost area, until the onset of the Late Holocene. In spite of the great resilience of these forests, the increasing recurrence of human disturbances, mostly related to grazing, has led them to isolated stands at high altitudes along watercourses.

Extinction has been the response to Holocene disturbances followed by Carpinus and a number of populations of the other studied tree species. Persistence of the rest is mainly the result of altitudinal shifts, without discarding a possible latitudinal migration of northern beech populations further south to the eastern sectors of the massif. Adaptation involves a controversial trait, but some microevolutionary adaptations are likely to have been shaped over the long history of these species.

Current global change and human disturbances put these populations, with likely unique and high genetic variation, on the edge of extinction. Urgent measures should be set up in these areas, as they constitute the only option of "in situ" conservation for these rare species which develope in small fragmented populations.

Future challenges are related to the study and protection of the "current interglacial refugia" where these tree species grow, in order to analyze their buffering capability, but also to the research on the ecological requirements of these species, as well as, particularly, on the understanding of their long history. In this sense, genetic studies on current populations could shed light to evolutionary changes. Moreover, well-dated and high-resolution palynological investigations are needed to find new evidences and support recent results.

\section{ACKNOWLEDGEMENTS}

This paper is part of the research carried our within the project "Dinámicas socio-ecológicas, resiliencia y vulnerabilidad en un paisaje de montaña: el Sistema Central $(9000$ cal. BC-1850 cal. AD) " (R\&D National Plan of the Spanish Government, HAR2013-43701-P). 


\section{REFERENCES}

Abel Schaad, D., Hernández Carretero, A.M., López Sáez, J.A., Pulido Díaz, F.J., López Merino, L. \& Martínez Cortizas, A. - 2009a - Evolución de la vegetación en la Sierra de Gata (Cáceres-Salamanca, España) durante el Holoceno reciente. Implicaciones biogeográficas Rev. Esp.Micropal. 41 (1-2): 91-105.

Abel Schaad, D., Hernández Carretero, A.M., López Merino, L., Pulido Díaz, F.J. \& López Sáez, J.A. -2009bCabras y quemorros: Tres siglos de cambios en el paisaje de la vertiente extremeña de la Sierra de Gredos - Rev. Est. Extrem. 65 (1): 449-478.

Abel-Schaad, D. - 2012 - Evolución de la vegetación durante el Holoceno reciente en la vertiente extremeña del Sistema Central a partir del análisis palinológico Mem. Doc. (inéd.). Univ. Extremadura, Plasencia.

Abel-Schaad, D., López-Sáez, J.A. - 2013 - Vegetation changes in relation to fire history and human activities at the Peña Negra mire (Béjar Range, Iberian Central Mountain System, Spain) during the past 4.000 years Veg. Hist. Archaeobot. 22: 199-214.

Abrantes, F., Voelker, A., Sierro, F., Naughton, F., Rodrigues, T., Cacho, I., Ariztegui, D., Brayshaw, D., Sicre, M.A. \& Batista, L. -2012 - Paleoclimate variability in the Mediterranean Region - In: Lionello, P. (Ed.). The climate of the Mediterranean region, from the past to the future. Elsevier.

Aizpuru, I. \& Catalán, P. - 1984- Presencia del carpe en la Península Ibérica - An. Jard. Bot. Madrid 41(1): 143-151.

Aitken, S.N., Yeaman, S., Holliday, J.A., Wang, T., \& Curtis-Mclane, S. - 2008 - Adaptation, migration or extirpation: climate change outcomes for tree populations Evol. Appl. 1(1): 95-111.

Alba-Sánchez, F., López-Sáez, J.A., De Benito, B., Linares, J.C., Nieto, D. \& López-Merino, L. - 2010- Past and present potential distribution of the Iberian Abies species: a phytogeographic approach using fossil pollen data and species distribution models - Divers. Distrib. 16: 214-228.

Allen, C.D., Macalady, A.K., Chenchouni, H., Bachelet, D., McDowell, N., Vennetier, M., Kitzberger, T., Rigling, A., Breshears, D.D., Hogg, E.H., Gonzalez, P., Fensham, R., Zhang, Z., Castro, J., Demidova, N., Lim, J.H., Allard, G., Running, S.W., Semerci, A. \& Cobb, N. -2010 - A global overview of drought and heat-induced tree mortality reveals emerging climate change risks for forests Forest Ecol. Manag. 259(4): 660-684.

Allouche, O., Tsoar, A. \& Kadmon, R. -2006- Assessing the Accuracy of Species Distribution Models: Prevalence, Kappa and the True Skill Statistic (TSS) - J. Appl. Ecol. 43 (6): 1223-1232

Alvarez Sanchís, J.R. -1997- Los Vettones: Arqueología de un pueblo protohistórico - Mem. Doc. (inéd.). Univ. Complutense, Madrid.

Amor, A., Ladero, M. \& Valle, C.J. - 1993 - Flora y vegetación vascular de la comarca de La Vera y laderas meri- dionales de la Sierra de Tormantos (Cáceres, España) Stud. Bot. 11: 11-207.

Andersen S.T. - 1970 - The relative pollen productivity and pollen representation of north European trees, and correction factors for tree pollen spectra - Dan. Geol. Unders. Række 2 96:1-99.

Andrade, A., Ruiz-Zapata, M.B., Gil-García, M.J., Fombe1la, M.A. - 1996- Acción antrópica y su impacto sobre la vegetación, desde el tránsito Subatlántico-Subboreal, en la vertiente norte de la Sierra de Gredos (Ávila, España) - In: Ruiz-Zapata, M.B. (Ed.). Estudio palinológico. Pp. 7-12. Univ. Alcalá de Henares, Alcalá de Henares.

Anonymous - 2013 - Sistema de información de las plantas de España - R. Jard. Bot. CSIC. Fund. Biodiversidad. Recurso electrónico en www.anthos.es

Apalategui, O., Contreras, F., Sánchez-Carretero, R., Eguiguren, E., Rubido, J.C. \& Bellido, F. -2006- Cabezuela del Valle. Hoja 576. Mapa Geológico de España 1:50.000. - Inst. Geol. Min. Esp., Madrid.

Ashcroft, M.B. -2010 - Identifying refugia from climate change - J. Biogeogr. 37: 1407-1413.

Atienza Ballano, M. - 1993 - Evolución del paisaje vegetal en las Sierras de Béjar y Francia durante el Holoceno, a partir del análisis polínico - Mem. Doc. (inéd.). Univ. Alcalá de Henares, Alcalá de Henares.

Bartlein, P.J., Harrison, S.P., Brewer, S., Connor, S., Davis, B.A.S., Gajewski, K., Guiot, J., et al. -2011 - Pollenbased continental climate reconstructions at 6 and $21 \mathrm{ka}$ : a global synthesis - Clim. Dynam. 37(3-4): 775-802.

Bennett, K.D. \& Provan, J. -2008- What do we mean by "refugia"? - Quat. Sci. Rev. 27(27-28): 2449-2455.

Bhagwat, S.A. \& Willis, K.J. -2008- Species persistence in northerly glacial refugia of Europe: a matter of chance or biogeographical trait? - J. Biogeogr. 35: 464-482.

Bjune, A.E., Helvik, I., \& Birks, H.J.B. -2013-The Fagus sylvatica forests in the Larvik region, south-eastern Norway: their origin and history - Veg. Hist. Archaeobot. 22: 215-229.

Blanco González, A., López Sáez, J.A. \& López Merino, L. -2009- Ocupación y uso del territorio en el sector centromeridional de la cuenca del Duero entre la Antigüedad y la Alta Edad Media (s. I-XI D.C.) - Arch. Esp. Arqueol. 82: 275-300.

Blanco-González, A. - 2010 - Arqueología de la población entre la Edad del Bronce y el Primer Hierro (1800-400 $\mathrm{AC})$ : sobre procesos migratorios y colonizadores en la Submeseta Norte - Arqueol. Espac. 28: 361-379.

Bond, G., Kromer, B., Beer, J., Muscheler, R., Evans, M.N., Showers, W., Hoffmann, S., Lotti-Bond, R., Hajdas, I., Bonani, G. - 2001 - Persistent solar influence of North Atlantic climate during the Holocene - Science 294: 2130-2136.

Braconnot, P., Otto-Bliesner, B., Harrison, S., Joussaume, S., Peterchmitt, J.Y., Abe-Ouchi, A., Crucifix, M., 
Driesschaert, E., Fichefet, Th., Hewitt, C.D., Kageyama, M., Kitoh, A., Laîné, A., Loutre, M.F., Marti, O., Merkel, U., Ramstein, G., Valdes, P., Weber, S.L., Yu, Y. \& Zhao, Y. - 2007- Results of PMIP2 Coupled Simulations of the Mid-Holocene and Last Glacial Maximum. Part 1: Experiments and Large-scale Features - Clim. Past 3(2): 261-277.

Bradshaw, R. H. W., Kito, N., \& Giesecke, T. -2010 - Forest Ecology and Management Factors influencing the Holocene history of Fagus - Forest Ecol. Manag. 259(11): 2204-2212.

Brayshaw, D.J., Rambeau, C.M.C. \& Smith, S.J. - $2011-$ Changes in Mediterranean climate during the Holocene: insights from global and regional climate modelling Holocene 21: 15-31.

Brewer, S., Cheddadi, R., de Beaulieu, J.L., Reille, M. \& data contributors - 2002 - The spread of deciduous Quercus throughout Europe since the last glacial period - Forest Ecol. Manag. 156: 27-48.

Brewer, S., Francoise, L., Cheddadi, R., Laurent, J.M. \& Favre, E. - 2009- Comparison of simulated and observed vegetation for the mid-Holocene in Europe Clim. Past Discuss. 5: 965-1011.

Brook, B.W., Sodhi, N.S., Bradshaw, C.J.A. -2008Synergies among extinction drivers under global change - Trends Ecol. Evol. 23 (8): 453-460.

Brus, R. - 2010- Growing evidence for the existence of glacial refugia of European beech (Fagus sylvatica L.) in the south-eastern Alps and north-western Dinaric Alps Period. Biol. 112(3): 239-246.

Brzeziecki, B. \& Kienast, F. - 1994-Classifying the lifehistory strategies of trees on the basis of the Grimian model - Forest Ecol. Manag. 69: 167-187.

Cacho, I., Valero Garcés, B. \& González Sampériz, P. 2010 - Revisión de las reconstrucciones paleoclimáticas en la Península Ibérica desde el último período glacial En: Pérez-Fiz, F. \& Boscolo, R. (eds.). Clima en España: pasado, presente y futuro, pp 9-24

Carrión, J.S., Fuentes, N., González-Sampériz, P., Sánchez, L., Finlayson, J.C., Fernández, S., Andrade, A. - 2007- Holocene environmental change in a montane region of southern Europe with a long history of human settlement Quat. Sci. Rev. 26: 1455-1475.

Carrión, J.S., Fernández, S., González-Sampériz, P., Gil-Romera, G., Badal, E., Carrión-Marco, Y., López-Merino, L., López-Sáez. J.A., Fierro, E. \& Burjachs, F. - 2010Expected trends and surprises in the Lateglacial and Holocene vegetation history of the Iberian Peninsula and Balearic Islands - Rev. Palaeobot. Palynol. 162: 458475.

Casaseca, B. - 1975 - Contribución al conocimiento de la flora salmantina. II - An. Inst. Bot. Cavanilles 32(2): 255-258.

Castroviejo, S., Laínz, M., López González, G., Montserrat, P., Muñoz Garmendia, F., Paiva, J. \& Villar, L. (Eds.). 1990 - Flora Ibérica. Plantas Vasculares de la Península Ibérica e Islas Baleares - R. Jard. Bot., CSIC, Madrid.
CCAFS Climate - 2013- GCM. Statistical Downscaling (Delta Method) - Accessed April 22. http://www.ccafsclimate.org/statistical_downscaling_delta/

Chala, D. - 2010 - Modelling the potential ecological niche of Fagus (Beech) Forest in Majella National Park, Italy - Thesis. International Institue for Geo-Information Science and Earth Observation. Belgium

Cheddadi, R., Yu, G., Guiot, J. \& Harrison, S.P. - 1997- The climate of Europe 6000 years ago - Clim. Dynam. 13: 1-9.

Colombaroli, D., Vannière, B., Emmanuel, C., Magny, M. \& Tinner, W. - 2008- Fire- vegetation interactions during the Mesolithic-Neolithic transition at Lago dell'Accesa, Tuscany, Italy - Holocene, 18 (5): 679-692.

Colombaroli, D., Henne, P.D., Kaltenrieder, P., Gobet, E. \& Tinner, W. - 2010 - Species responses to fire, climate and human impact at tree line in the Alps as evidenced by palaeo-environmental records and a dynamic simulation model - J. Ecol. 98 (6): 1346-1357

Colombaroli, D., Beckmann, M., Van der Knaap, W.O., Curdy, P. \& Tinner, W. - 2013- Changes in biodiversity and vegetation composition in the central Swiss Alps during the transition from pristine forest to first farming Div. Distrib. 19 (2): 157-170

Conedera, M., Tinner, W., Crameri, S., Torriani, D. \& Herold, A. -2006- Taxon-related pollen source areas for lake basins in the southern Alps: an empirical approach Veget. Hist. Archaeobot. 15: 263-272

Connor, S.E., Araújo, J., Van der Knaap, W.O. \& Van Leeuwen, J.F.N. -2012 - A long-term perspective on biomass burning in the Serra da Estrela, Portugal - Quat. Sci. Rev. 55: 114-124

Costa Tenorio, M., Morla Juaristi, C. \& Sainz Ollero, H. (Eds.) - 1997 - Los bosques ibéricos. Una interpretación geobotánica. Planeta, Barcelona

Cuatrecasas, J. - 1932 - Die Verbreitung von Fagus sylvatica auf der Iberischen Halbinsel. Veréff. Geobot. Insí. ETH Stiftung Rúbel, 8:1-21. Zurich

Currás, A., Zamora, L., Reed, J.M., García-Soto, E., Ferrero, S., Armengol, X., Mezquita-Joanes, F., Marqués, M.A., Riera, S. \& Julià, R. - 2012- Climate change and human impact in central Spain during Roman times: High-resolution multi-proxy analysis of a tufa lake record (Somolinos, $1280 \mathrm{~m}$ asl) - Catena 89: 31-53

David, F. \& Barbero, M. - 1995 - De l'histoire du genre Betula dans les Alpes Françaises du Nord - Rev.Palaeobot. Palynol. 89: 455-467

Davis, M.B., Shaw, R. \& Etterson, J.R. - 2005 - Evolutionary responses to changing climate - Ecology 86(7): 1704-1714

De Nascimento, L., Willis, K.J., Fernández-Palacios, J.M., Criado, C., Whittaker, R.J., -2008 - The long-term ecology of the lost forests of La Laguna, Tenerife (Canary Islands) - J. Biogeogr. 36(3): 499-514

Devesa Alcaraz, J.A. - 1995- Vegetación y Flora de Extremadura - Universitas Ed., Badajoz

De Vicente, G., González Casado, J.M., Calvo, J.P., Muñoz Martín, A., Giner, J. \& Rodríguez Pascua, M. -1994- 
Evolución y estructuras alpinas en la zona del centro peninsular - Cad. Lab. Xeol. Laxe, 19, 175-190.

Dobrowski, S.Z. - 2011 - A climatic basis for microrefugia: the influence of terrain on climate - Glob.Change Biol. 17:1022-1035.

Dormoy, I., Peyron, O., Combourieu Nebout, N., Goring, S., Kotthoff, U., Magny, M., \& Pross, J. -2009- Terrestrial climate variability and seasonality changes in the Mediterranean region between 15000 and 4000 years BP deduced from marine pollen records - Clim. Past 5(4): 615-632

Dubreuil, M., Riba, M., González-Martínez, S.C., Vendramin, G.G., Sebastiani, F. \& Mayol, M. -2010- Genetic effects of chronic habitat fragmentation revisited: strong genetic structure in a temperate tree, Taxus baccata L. (Taxaceae), with great dispersal capability Am. J. Bot. 97: 303-310.

Fabián García, J.F. -2006- El IV y III Milenio AC en el Valle Amblés (Ávila). Monografías 5: Arqueología en Castilla y León. Junta de Castilla y León.

Fabián, J.F., Blanco González, A. \& López Sáez, J.A. 2006 - La transición Calcolítico-Bronce Antiguo desde una perspectiva arqueológica y ambiental: el Valle Amblés (Ávila) como referencia - Arq. Esp. 26: 37-56.

Faegri, K. \& Iversen, J. - 1989- Textbook of Pollen Analysis. 4th Edn - John Wiley \& Sons, Chichester.

Fernández Díez, F.J. - 1976- Flora vascular de la sierra de Tamames y Peña de Francia (Salamanca). II - Trab. Dept. Bot. Salamanca I: 3-27

Fernández-Posse, M.D. - 1998 - La investigación protohistórica en la Meseta y Galicia - Ed. Síntesis, Madrid.

Fineschi, S., Salvini. D., Taurchini, D., Carnevale, S. \& Vendramin, G.G. -2003 - Chloroplast DNA variation of Tilia cordata Mill. (Tiliaceae) - Can. J. Forest Res. 33: 2503-2508

Finsinger, W., Colombaroli, D., De Beaulieu, J.-L., Valsecchi, V., Vannière, B., Vescovi, E., Chapron, E., Lotter, A.F., Magny, M. \& Tinner, W. - 2010 - Early to midHolocene climate change at Lago dell'Accesa (central Italy): climate signal or anthropogenic bias? - J. Quat. Sci. 25(8): 1239-1247.

Franco Múgica, F. - 1995- Estudio palinológico de turberas holocenas en el Sistema Central: reconstrucción paisajística y acción antrópica - Tesis Doctoral, Universidad Autónoma, Madrid.

Franco-Múgica, F., García-Antón, M., Sainz-Ollero, H. 1998 - Vegetation dynamics and human impact in the Sierra de Guadarrama, Central System, Spain - Holocene 8: 69-82.

Franco Múgica, F., García Antón, M., Maldonado Ruiz, J., Morla Juaristi, C. \& Sainz Ollero, H. -2001 - Evolución de la vegetación en el sector septentrional del Macizo de Ayllón (Sistema Central). Análisis polínico de la turbera de Pelagallinas - An. Jard. Bot. Madrid 59 (1): 113-124.

Franco-Múgica, F. - 2009 - El análisis polínico en la reconstrucción del paisaje vegetal - In: Génova, M., Gómez-Manzaneque, F., Morla-Juaristi, C. (eds.). Los bosques de Gredos a través del tiempo. Pp. 89-117. Junta de Castilla y León, Valladolid.

Frigola, J., Moreno, A., Cacho, I., Canals, M., Sierro, F.J., Flores, J.A, Grimalt, J.O., Hodell, D.A. \& Curtis, J.H. -2007 - Holocene climate variability in the western Mediterranean region from a deepwater sediment record - Paleoceanogr. 22(2), PA2209, doi:10.1029/2006PA001307.

García, D., Zamora, R., Hódar, J.A, Gómez, J.M. \& Castro, J. $-2000-$ Yew (Taxus baccata L.) regeneration is facilitated by fleshy-fruited shrubs in Mediterranean environments - Biol. Conserv. 95: 31-38.

García Amorena, I., Gómez Manzaneque, F., Rubiales, J.M., Granja, H.M., Soares de Carvalho, G. \& Morla, C. 2007 - The Late Quaternary coastal forests of western Iberia: A study of their macroremains - Palaeogeogr. Palaeoclim. Palaeoecol. 254: 448-461

Gavilán, R., Fernández-González, F. \& Blasi, C. -1998Climatic classification and ordination of the Spanish Sistema Central: relationships with potential vegetation Plant Ecol. 139: 1-11.

Giesecke, T., Hickler, T., Kunkel, T., Sykes, M.T. \& Bradshaw, R.H.W. - 2007 - Towards an understanding of the Holocene distribution of Fagus sylvatica L. - J. Biogeogr. 34: 118-131

Giesecke, T., Bennett, K. D., Birks, H. J. B., Bjune, A. E., Bozilova, E., Feurdean, A., Finsinger, W., et al. 2011 - The pace of Holocene vegetation change - testing for synchronous developments - Quat. Sci. Rev. 30(19-20): 2805-2814.

Gil García, M.J. - 1992 - Dinámica de la paleovegetación en el sector oriental del Sistema Central español durante el Holoceno, en base al análisis polínico. Implicaciones climáticas - Mem. Doc. (inéd.). Univ. Alcalá de Henares, Alcalá de Henares.

Gil-García, M.J., Tomás Las Heras, R., Ruiz-Zapata, M.B. -1996- Paleovegetation, climate and human action during the Upper Holocene at Morcuera Pass (Madrid, Spain) - Rev. Paléobiol. 15: 469-478.

Gil-Romera, G., Carrión, J.S., Pausas, J.G., Sevilla-Callejo, M., Lamb, H.F., Fernández, S. \& Burjachs, F. -2010Holocene fire activity and vegetation response in SouthEastern Iberia - Quat. Sci. Rev. 29: 1082-1092.

Gómez, A. \& Lunt, D.H. - 2007- Refugia within refugia: patterns of phylogeographic concordance in the Iberian Peninsula - In: Weiss, S. \& Ferrand, N. (eds.). Phylogeography of southern European refugia. Pp. 155-188. Springer-Verlag, Amsterdam.

González-Martínez, S.C., Dubreuil, M., Riba, M., Vendramin, G.G., Sebastiani, F. \& Mayol, M. -2010- Spatial genetic structure of Taxus baccata $\mathrm{L}$. in the western Mediterranean Basin: past and present limits to gene movement over a broad geographic scale - Mol. Phylogenet. Evol. 55: 805-815.

Gottfried, M., Pauli, H., Futschik, A., Akhalkatsi, M., Barancok, P., Benito, J.L. et al. -2012- Continent-wide response of mountain vegetation to climate change - 
Nature Clim. Change Lett. 2(111-115), doi:10.1038/nclimate 1329

Granier, A., Biron, P. \& Lemoine, D. -2000 - Water balance, transpiration and canopy conductance in two beech stands - Agr. Forest Meteorol. 100(4): 291-308.

Grant, M.J., Waller, M.P. \& Groves, J.A. - 2011- The Tilia decline: vegetation change in lowland Britain during the mid and late Holocene - Quat. Sci. Rev. 30 (34): 394-408.

Grivet, D. \& Petit, R.J. -2003 - Chloroplast DNA phylogeography of the hornbeam in Europe: Evidence for a bottleneck at the outset of postglacial colonization Conserv. Genet. 4: 47-56.

Guisan, A., Edwards Jr, T.C. \& Hastie, T. -2002- Generalized Linear and Generalized Additive Models in Studies of Species Distributions: Setting the Scene - Ecol. Model. 157(2-3): 89-100.

Hampe, A., Petit, R.J. -2005 - Conserving biodiversity under climate change: the rear edge matters - Ecol. Lett. 8: 461-467.

Hampe, A. \& Jump, A.S. - 2011 - Climate Relicts: Past, Present, Future - Ann. Rev. Ecol. Evol. S. 42: 313-333.

Henne, P.D., Elkin, C., Colombaroli, D., Samartin, S., Bugmann, H., Heiri, O. \& Tinner, W. - 2013 - Impacts of changing climate and land use on vegetation dynalics in a Mediterranean ecosystem: insights from paleoecology and dynamic modelling — Landscape Ecol. 28: 819-833.

Hernández Bermejo, J.E. \& Sainz Ollero, H. - 1984 - Ecología de los hayedos meridionales ibéricos: el macizo de Ayllón - Serv. Publ. Agr. Min. Agric. Pesc. Alim., Madrid.

Hewitt, G.M. - 2001 - Speciation, hybrid zones and phylogeography-or seeing genes in space and time Mol. Ecol. 10: 537-549.

Hijmans, R.J., Cameron, S.E., Parra, J.L., Jones, P.G. \& Jarvis, A. - 2005 - Very High Resolution Interpolated Climate Surfaces for Global Land Areas - Int. J. Climatol. 25(15): 1965-1978.

Hilfiker, K., Holderegger, R., Rotach, P., \& Gugerli, F. 2004- Dynamics of genetic variation in Taxus baccata: local versus regional perspective - Can. J. Bot. 82: 219227.

Jacobson, G.L. Jr \& Bradshaw, R.H.W. -1981- The selection of sites for paleovegetational studies - Quat. Res. 16: 80-96.

Jalut, G., Amat, A.A., Bonnet, L., Gauquelin, T. \& Fontugne, M. - 2000- Holocene climatic changes in theWestern Mediterranean, from south-east France to south-east Spain - Palaeogeogr. Palaeoclim. Palaeoecol. 160: 255-290.

Jalut, G., Dedoubat, J.J., Fontugne, M. \& Otto, T. - 2009Holocene circum-Mediterranean vegetation changes: Climate forcing and human impact - Quat. Int. 200 (12): 4-18.

Janssen, C. \& Woldringh, R.E. - 1981 - A preliminary radiocarbon dated pollen sequence from the Serra da Estrela, Portugal - Finisterra 16(32): 299-309.
Joannin, S., Vanniere, B., Galop, D., Peyron, O., Haas, J.N., Gilli, A., Chaprom, E., Wirth, S.B., Anselmetti, F., Desmet, M. \& Magny, M. - 2012- Climate and vegetation changes during the Lateglacial and Early-Mid Holocene at Lake Ledro (Southern Alps, Italy ) - Clim. Past 9: 913-933.

Jump, A.S., Hunt, J.M. \& Peñuelas, J. - 2006- Rapid climate change-related growth decline at the southern range edge of Fagus sylvatica - Glob. Change Biol. 12: 2163-2174.

Jump, A.S., Matyas, C. \& Peñuelas, J. -2009- The altitude-for-latitude disparity in range retractions of woody species - Trends Ecol. Evol. 24 (12): 694-701.

Harumi, H. \& Emori, S. (eds.) - 2004-K-1 Coupled Model (MIROC) Description - K-1 model developers. Center for Climate System Research (CCSR), University ofTokyo. National Institute for Environmental Studies (NIES). Frontier Research Center for Global Change (FRCGC), Tokyo. 34 pp. http://ccsr.aori.utokyo.ac.jp/ hasumi/miroc_description.pdf.

Keppel, G., Niel, K.P. Van, Wardell-Johnson, G.W., Yates, C.J., Byrne, M., Mucina, L., Schut, A.G., Hopper, D. \& Franklin, S.E. - 2012- Refugia: identifying and understanding safe havens for biodiversity under climate change - Global Ecol. Biogeogr. 21: 393-404.

Knaap, W. O. Van Der, Leeuwen, J. F. N. Van, Finsinger, W., Gobet, E., Pini, R., Schweizer, A., Valsecchi, V., 2005- Migration and population expansion of Abies , Fagus, Picea and Quercus since 15000 years in and across the Alps, based on pollen-percentage threshold values - Quat. Sci. Rev. 24: 645-680.

Kobashi, T., Severinghaus, J. P., Brook, E. J., Barnola, J.M., \& Grachev, A. M. -2007- Precise timing and characterization of abrupt climate change 8200 years ago from air trapped in polar ice - Quat. Sci. Rev. 26(9-10): 1212-1222.

Körner, C. \& Ohsawa, M. - 2005- Mountain systems In: Hassan R., Scholes, R. \& Ash, N. (Eds.). Ecosystems and human well-being: current state and trends, Vol 1. Chapter 24. Island press. Washington D.C.

Kramer, K., Degen, B., Buschbom, J., Hickler, T., Thuille r, W., Sykes, M.T. \& Winter, W. -2010- Modelling exploration of the future of European beech (Fagus sylvatica L.) under climate change. Range, abundance, genetic diversity and adaptive response - Forest Ecol. Manag. 259: 2213-2222.

Krebs, P., Conedera, M., Pradella, M., Torriani, M., Felber, D. \& Tinner, W. -2004- Quaternary refugia of the sweet chesnut (Castanea sativa Mill.): an extended palynological approach - Veg. Hist. Archeobot. 13, 145-160

Laguna, M. - 1883 - Flora forestal española - Min. Fomento, Madrid.

Lavergne, S., Mouquet, N., Thuiller, W. \& Ronce, O. 2010- Biodiversity and Climate Change: Integrating Evolutionary and Ecological Responses of Species and Communities - Ann. Rev. Ecol. Evol. S. 41: 321-350.

Lenoir, J. \& Svenning, J.C. - 2013 - Latitudinal and elevational range shifts under contemporary climate change 
- In: Levin, S. (Ed.). Encyclopedia of Biodiversity. Geogr. Global Issues. Waltham Acad. Press.

Leresche, L. \& Levier, E. - 1880 - Deux excursions botaniques dans le nord de l'Espagne et le Portugal - Imp. G. Bridel, Lausanne.

Leuschner, C., Meier, I. C. \& Hertel, D. -2006- On the niche breadth of Fagus sylvatica: soil nutrient status in 50 Central European beech stands on a broad range of bedrock types - Ann. Forest Sci. 63: 355-368.

Linares, J. C. -2013 - Forest Ecology and Management Shifting limiting factors for population dynamics and conservation status of the endangered English yew (Taxus baccata L., Taxaceae ) - Forest Ecol. Manag. 291: 119-127.

Liu, C., Berry, P.M., Dawson, T.P. \& Pearson, R.G. -2005Selecting Thresholds of Occurrence in the Prediction of Species Distributions - Ecography 28 (3): 385-393

Ljungqvist, F.C. - 2011 - The Spatio-Temporal Pattern of the Mid-Holocene Thermal Maximum - Geografie 116 (2): 91-110.

López-Merino, L., López Sáez, J.A., Ruiz Zapata, M.B. \& Gil García, M.J. - 2008 - Reconstructing the history of beech (Fagus sylvatica L.) in the north-western Iberian Range (Spain): From Late-Glacial refugia to the Holocene anthropic-induced forests - Rev. Palaeobot. Palynol.152: 58-65

López Sáez, J.A. -1993 - Las alisedas (Scrophulario-Alnetum glutinosae) del Valle del Tiétar (Sierra de Gredos, Ávila): estado de conservación y presencia de especies relícticas del Terciario y Pliocuaternario - In: Silva, F.J. \& Vega Alonso, G. (Eds.). I Congreso Forestal Español (vol. IV). Pp. 41-46. Pontevedra.

López-Sáez, J.A. \& López-García, P. - 1994- Contribution of the palaeoecological knowledge of Quaternary in the Tietar Valley (Sierra de Gredos, Ávila, Spain) Rev. Esp. Micropal. 26: 61-66.

López-Sáez, J.A., Blanco-González, A., -2005 - La mutación Bronce Final/Primer Hierro en el suroeste de la Cuenca del Duero (provincia de Ávila): ¿cambio ecológico y social? - In: Blanco, A., Cancelo, C., Esparza, A. (Eds.). Bronce Final y Edad del Hierro en la Península Ibérica. Pp. 229-250. Univ. Salamanca, Salamanca.

López-Sáez, J.A., \& López-Merino, L. -2007- Coprophilous fungi as a source of information of anthropic activities during the Prehistory in the Amblés Valley (Ávila, Spain): The archaeopalynological record - Rev. Esp. Micropaleontol. 39: 103-116

López-Sáez, J.A., López-Merino, L. \& Pérez-Díaz, S. 2008 - Crisis climáticas en la Prehistoria de la Península Ibérica: el Evento $8200 \mathrm{cal}$. BP como modelo - In: Rovira Llorens, S., García Heras, M., Gener Moret, M., Montero, I. (eds.). Actas VII Congreso Ibérico de Arqueometría (Madrid, 8-10 octubre 2007). Pp. 77-86. Min. Educ. Ci. Mus. Arq. Nac. CSIC, Madrid.

López-Sáez, J.A., Blanco-González, A., López-Merino, L., Ruiz-Zapata, M.B., Dorado-Valiño, M., Pérez-Díaz, S., Valdeolmillos, A. \& Burjachs, F. -2009- Landscape and climatic changes during the end of the Late Prehistory in the Ambles Valley (Ávila, Central Spain), from 1200 to 400 cal BC - Quat. Int. 200: 90-101.

López-Sáez, J.A., López-Merino, L., Alba-Sánchez, F., Pérez-Díaz, S. - 2009b-Contribución paleoambiental al estudio de la trashumancia en el sector abulense de la Sierra de Gredos - Hispania 69: 9-38.

López-Sáez, J.A., Abel-Schaad, D., Pérez-Díaz, S., BlancoGonzález, A., Alba-Sánchez, F., Dorado, M., Ruiz-Zapata, M.B., Gil-García, M.J., Gómez-González, C. \& FrancoMúgica, F. - 2013 - Vegetation history, climate and human impact in the Spanish Central System over the last 9,000 years - Quat. Int. http://dx.doi.org/10.1016 /j.quaint.2013.06.034.

López-Sáez, J.A., Sánchez-Mata, D., Alba-Sánchez, F., Abel-Schaad, D., Gavilán, R.G. \& Pérez-Díaz, S. 2013 - Discrimination of Scots pine forests int he Iberian Central System (Pinus sylvestris var. iberica) by means of pollen analysis. Phytosociological considerations - Lazaroa 34: 191-208.

Magny, M., Vannière, B., Zanchetta, G., Fouache, E., Touchais, G., Petrika, L., Coussot, C., Walter-Simonnet, A.V., Arnaud, F. -2009- Possible complexity of the climatic event around 4300-3800 cal. BP in the central and western Mediterranean - Holocene 19: 823-833.

Magny, Michel, Vannière, B., Calo, C., Millet, L., Leroux, A., Peyron, O., Zanchetta, G., La Matia, T. \& Tinner, W. -2011 - Holocene hydrological changes in south-western Mediterranean as recorded by lake-level fluctuations at Lago Preola, a coastal lake in southern Sicily, Italy Quat. Sci. Rev. 30(19-20): 2459-2475.

Magny, Michel, Peyron, O., Sadori, L., Ortu, E., Zanchetta, G., Vannière, B., \& Tinner, W. -2012- Contrasting patterns of precipitation seasonality during the Holocene in the south- and north-central Mediterranean - J. Quat. Sci. 27(3): 290-296.

Magri, D. - 2008 - Patterns of postglacial spread and the extent of glacial refugia of European beech (Fagus sylvatica) - J.Biogeogr. 35: 450-463.

Magri, D., Vendramin, G.G., Comps, B., Dupanloup, I., Geburek, T., Gömöry, D., Latałowa, M., Litt, T., Paule, L., Roure, J.M., Tantau, I., van der Knaap, W.O., Petit, R.J. \& de Beaulieu, J.L. -2006- A new scenario for the Quaternary history of European beech populations: palaeobotanical evidence and genetic consequences New Phytol. 171: 199-221.

Magyari, E. - 2002 - Holocene biogeography of Fagus sylvatica L. and Carpinus betulus L. in the CarpathianAlpine Region - Fol. Hist. Nat. Mus. Matr. 26: 15-35. Martín-Puertas, C., Jiménez-Espejo, F., Martínez-Ruiz, F., Nieto-Moreno, V., Rodrigo, M., Mata, M.P., \& ValeroGarcés, B.L. - 2010 - Late Holocene climate variability in the southwestern Mediterranean region: an integrated marine and terrestrial geochemical approach - Clim. Past 6(6): 807-816.

Martínez Atienza, F. \& Morla Juaristi, C. -1992- Aproximación a la paleocorología de Fagus en la Península 
Ibérica a través de datos paleopolínicos - Inv. Agrar. Sist. Rec. For. fuera serie 1(2): 3-12.

Martínez-Cortizas, A., Costa-Casais, M. \& López-Sáez, J.A. -2009- Environmental change in NW Iberia between 7000 and $500 \mathrm{cal} \mathrm{BC} \mathrm{-} \mathrm{Quat.} \mathrm{Int.} \mathrm{200:} \mathrm{77-89.}$

Martín Velázquez, S. \& Elorza, F.J. - 2007- Deformación cenozoica de la litosfera Ibérica: Sistema Central y cuencas del Duero y Tajo - Geogaceta 42: 11-14.

Mayewski, P.A., Rohling, E.E., Stager, J.C., Karlen W., Maasch K.A., Meeker, L.D., Meyerson, E.A., Gasse, F., Van Kreveld, S. \& Holmgren, K. -2004- Holocene climate variability - Quat. Res. 62: 243-255.

Mayor, M. -1965 - Estudio de la flora y vegetación de las sierras de Pela, Ayllón y Somosierra - Mem. Doc. (inéd.). Univ. Complutense, Madrid.

Médail, F. \& Diadema, K. -2009- Glacial refugia influence plant diversity in the Mediterranean Basin - J. Biogeogr. 36: 1333-1345.

Moore, P.D., Webb, J.A., \& Collinson, M.E. -1991 - Pollen analysis - Blackwell Sci. Publ., Londres.

Morales-Molino, C., García-Antón, M., Postigo-Mijarra, J.M., Morla, C., -2013- Holocene vegetation, fire and climate interactions on the westernmost fringe of the Mediterranean Basin - Quat. Sci. Rev. 59: 5-17.

Muñoz Barco, P. \& Martínez Flores, E. (Coords.). -2005Patrimonio Geológico de Extremadura. Geodiversidad y Lugares de Interés Geológico - Junta Extremadura. Cons. Agric. Med. Amb.

Nieto Feliner, G. -2011 - Southern European glacial refugia: A tale of tales - Taxon 60(2): 365-372

Nieto-Moreno, V., Martínez-Ruiz, F., Giralt, S., JiménezEspejo, F., Gallego-Torres, D., Rodrigo-Gámiz, M., García-Orellana, J., Ortega-Huertas, M. \& de Lange, G.J. -2011 - Tracking climate variability in the western Mediterranean during the Late Holocene: a multiproxy approach - Clim. Past Discuss. 7: 635-675

Nogués-Bravo, D. -2009- Predicting the Past Distribution of Species Climatic Niches - Global Ecol. Biogeogr. 18(5): 521-531

Noryskiewicz A.M. - 2003 - Modern pollen deposition in the Taxus reserve in the Wierzchlas (northern Poland) 16th INQUA Congres. Reno.

Otto-Bliesner, B.L., Brady, E.C., Clauzet, G., Tomas, R., Levis, S. \& Kothavala, Z. -2006 - Last Glacial Maximum and Holocene Climate in CCSM3 - J. Clim. 19(11): 2526-2544

Parmesan, C. - 2006 - Ecological and evolutionary responses to recent climate change - Annu. Rev. Ecol. Evol. Syst. 37, 637-669

Pautasso, M. - 2009- Geographical genetics and the conservation of forest trees - Perspect. Plant Ecol. 11(3): 157-189

Pearman, P.B., Randin, C.F., Broennimann, O., Vittoz, P., van der Knaap, W.O., Engler, R., Le Lay, G., Zimmermann, N.E. \& Guisan, A. - 2008 - Prediction of plant species distributions across six millennia - Ecol. Lett. 11: 357-369.
Pedraza. J. -1994 - Los modelos genético-evolutivos del Sistema Central Español: Implicaciones Morfotectónicas - Cad. Lab. Xeol. Laxe 19: 91-118.

Pedraza, J. \& Carrasco, R.M. -1999- Morfotectónica del Sistema Central Español. Ideas actuales - Stud. Geol. Salamanca vol. esp. 7: 51-71.

Pedraza, J. \& Carrasco, R.M. - 2006 - El glaciarismo Pleistoceno del Sistema Central - Rev. Asoc. Esp. Ens. Ci. Tierra 13(3): 278-288.

Peinado Lorca, M. \& Rivas-Martínez, S. (Eds.). - 1987La vegetación de España - Col. Aula Abierta, Univ. Alcalá de Henares, Alcalá de Henares.

Pélachs, A., Pérez-Obiol, R., Ninyerola, M. \& Nadal, J. 2009- Landscape dynamics of Abies and Fagus in the southern Pyrenees during the last 2200 years as a result of anthropogenic impacts - Rev. Paleobot. Palynol. 156 (3-4): 337-349.

Pérez-Díaz, S., López-Sáez, J.A., Ruiz-Alonso, M., Zapata, L. \& Abel-Schaad, D. - 2013- Holocene history of Taxus baccata in the Basque Mountains (Northern Iberian Peninsula) - Lazaroa 33: 29-41.

Pérez-Obiol, R., Jalut, G., Julià, R., Pélachs, A., Iriarte, M.J., Otto, T. \& Hernández-Beloqui, B. -2011- Mid-Holocene vegetation and climatic history of the Iberian Peninsula - Holocene 21: 75-93.

Perrin, P.M. \& Mitchell, F.J.G. - 2013 - Effects of shade on growth, biomass allocation and leaf morfology in European yew (Taxus baccata L.) - Europ. J. For. Res. 132: 211-218.

Petit, R.J., Aguinagalde, I., de Beaulieu, J.L., Bittkau, C., Brewer, S., Cheddadi, R., Ennos, R., Fineschi, S., Grivet, D., Lascoux, M., Mohanty, A., Müller-Starck, G., DemesureMusch, B., Palmé, A., Martín, J. P., Rendell, S. \& Vendramin, G.G. -2003 - Glacial refugia: hotspots but not melting pots of genetic diversity - Science 300: 1563-1565.

Petit, R.J., Hampe, A. \& Cheddadi, R. - 2005- Climate changes and tree phylogeography in the Mediterranean - Taxon 54: 877-885.

Peyron, O., Goring, S., Dormoy, I., Kotthoff, U., Pross, J., De Beaulieu, J.L., Drescher-Schneider, R., Vannière, B. \& Magny, M. -2011- Holocene seasonality changes in the central Mediterranean region reconstructed from the pollen sequences of Lake Accesa (Italy) and Tenaghi Philippon (Greece) - Holocene 21(1): 131-146.

Peyron, O., Magny, M., Goring, S., Joannin, S., De Beaulieu, J.L., Brugiapaglia, E., Sadori, L., Garfi, G., Kouli, K., Ioakim, C. \& Combourieu-Nebout, N. -2012Contrasting patterns of climatic changes during the Holocene in the Central Mediterranean (Italy) reconstructed from pollen data - Clim. Past Discuss. 8(6): 5817-5866.

Phillips, S.J., Anderson, R.P. \& Schapire, R.E. -2006Maximum Entropy Modelling of Species Geographic Distributions - Ecol. Model. 190 (3-4): 231-259.

Pigott, C.D. \& Huntley, J.P. - 1981 - Factors controlling the distribution of Tilia cordata at the northern limits of its geographical range. III. Nature and causes of seed sterility — New Phytologist 87(4): 817-839. 
Pigott, C. D. - 1991 - Biological flora of the British Isles. Tilia cordata Miller - J. Ecol. 79: 1147-1207.

Pinto, P.E. \& Gegout, J.C. - 2005- Assessing the nutritional and climatic response of temperate tree species in the Vosges Mountains - Ann. Forest Sci. 62: 761-770.

Pokorny, P. - 2005 - Role of man in the development of Holocene vegetation in Central Bohemia - Preslia 77: 113-128.

Poska, A. \& Pidek, I.A. - 2010 - Pollen dispersal and deposition characteristics of Abies alba, Fagus sylvatica and Pinus sylvestris, Roztocze region (SE Poland) Veg. Hist. Archaeobot. 19: 91-101.

Postigo, J.M., Gómez Manzaneque, F. \& Morla, C. 2008 - Survival and long-term maintenance of tertiary trees in the Iberian Peninsula during the Pleistocene: first record of Aesculus L. (Hippocastanaceae) in Spain Veg. Hist. Archaeobot. 17(4): 351-364.

Postigo-Mijarra, J.M., Morla, C., Barrón, E., Morales-Molino, C. \& García, S. -2010- Patterns of extinction and persistence of Arctotertiary flora in Iberia during the Quaternary - Rev. Paleobot. Palynol. 62: 416-426.

Pulido, F., Sanz, R., Abel, D., Ezquerra, J., Gil, A., González, G., Hernández, A., Moreno, G., Pérez, J.J., \& Vázquez, F. -2007- Los bosques de Extremadura, evolución, ecología y conservación - Junta de Extremadura. Mérida.

Radoglou, K., Dobrowolska, D., Spyroglou, G. \& Nicolescu, V.N. - 2008 - A review on the ecology and silviculture of limes (Tilia cordata Mill., Tilia platyphyllos Scop. and Tilia tomentosa Moench.) in Europe http://www.valbro.uni-freiburg.de. 29 pp.

Ramil-Rego, P., Rodríguez Guitián, M.A., Muñoz Sobrino, C. \& Gomez-Orellana, L. - 2000- Some considerations about the postglacial history and recent distribution of Fagus sylvatica in the NW Iberian Peninsula - Folia Geobot. 35: 241-271.

Rivas-Martínez, S. - 1962- Contribución al estudio fitosociológico de los hayedos españoles - An. Inst. Bot. Cavanilles 20: 97-128.

Rivas-Martínez, S. - 1963- Estudio de la vegetación y flora de las Sierras de Guadarrama y Gredos - An. Inst. Bot. Cavanilles 21(1): 5-325.

Rivas-Martínez, S., Belmonte, D., Cantó, P., FernándezGonzález, F., Fuente, V., Moreno, J.M., Sánchez-Mata, D. \& Sancho, L.G. - 1987- Piornales, enebrales y pinares oro-mediterráneos (Pino-Cytision oromediterranei) en el Sistema Central - Lazaroa 7: 93-124.

Rivas Mateos, M. - 1898 - Flora de la provincia de Cáceres - An. Inst. Bot. Cavanilles 30: 235-255.

Robledo-Arnuncio, J.J., Collada, C., Alía, R. \& Gil, L. 2005 - Genetic structure of montane isolates of Pinus sylvestris L. in a mediterranean refugial area $-\mathrm{J}$. Biogeogr. 32: 595-605.

Ruiz del Castillo, J. -1993 - Análisis palinológico de nueve perfiles turbosos cuaternarios en el sector oriental del Sistema Central Español - Mem. Doc. (inéd.). Univ. Complutense, Madrid.
Ruiz de la Torre, J. - 1990 - Mapa Forestal de España ICONA. MAPA. Madrid.

Ruiz-Labourdette, D., Nogués-Bravo, D., Sáinz Ollero, H., Schmitz, M. F., \& Pineda, F. D. - 2012 - Forest composition in Mediterranean mountains is projected to shift along the entire elevational gradient under climate change - J. Biogeogr. 39: 162-176.

Ruiz-Zapata, M.B. \& Acaso, E. - 1981 - Análisis polínico de una turbera localizada en el Glaciar de Los Conventos (Macizo Central de Gredos - Ávila) - Bot. Macaron. 8-9, 249-253.

Ruiz-Zapata, M.B., Gil-García, M.J., Dorado, M., Valdeolmillos, A., Martín, T., Andrade, A. - 1998- Vegetación y paleoambientes en el Sistema Central Español - Bol. Not. A.P.L.E. 1: 12-24.

Ruiz-Zapata, M.B., Carrasco, R.M., Gil-García, M.J., Pedraza, J., Razola, L., Domínguez-Villar, D., Gallardo, J.L. -2011 - Dinámica de la vegetación durante el Holoceno en la Sierra de Gredos (Sistema Central Español) - Bol. R. Soc. Esp. Hist. Nat. (Sec. Geol.) 105: 109-123.

Sánchez Palencia, F.J., Ruiz del Arbol, M. \& López Jiménez, O. - 2003 - Tierra, Agua y Oro. Arqueología del Paisaje en la Sierra de Francia - Mus. Salamanca. Junta Castilla y León. Cons. Cult. Tur.

Sánchez Palomares, O., Rubio, A. \& Blanco, A. -2004Definición y cartografía de las áreas potenciales fisiográfico-climáticas de hayedo en España - Inv. Agrar. Sist. Rec. For. fuera de serie: 13-62.

Sanz, R., Pulido, F., Camarero, J. - 2011 - Boreal trees in the Mediterranean: recruitment of downy birch (Betula alba) at its southern range limit - Ann. For. Sci. 68: 793-802.

Sanz, R., Pulido F., Nogués-Bravo, D. -2009- Predicting mechanisms across scales: amplified effects of abioticconstraints in the recruitment of yew Taxus baccata Ecography 32: 1-8.

Sardinero, S. - 2004- Flora y Vegetación del macizo occidental de la Sierra de Gredos (Sistema Central, España) - Guineana 10: 15-436.

Sherrat, A.G. - 1981 - Plough and pastoralism: aspects of the secondary products revolution - In: Hodder,I.(Ed.). Pattern of the past.Pp. 261-305. Cambridge Univ. Press, Cambridge.

Skov, F. \& Svenning, J.C. - 2004 - Potential Impact of Climatic Change on the Distribution of Forest Herbs in $\mathrm{Eu}-$ rope - Ecography 27 (3): 366-380.

Stewart, J.R., Lister, A.M., Barnes, I. \& Dale, L. -2010_Refugia revisited: individualistic responses of species in space and time - Proc. Royal Soc. B 277: 661-671

Svejgaard Jensen, J. - 2003 - EUFORGEN Technical Guidelines for genetic conservation and use for lime (Tilia spp.) - Int. Plant Gen. Res. Inst., Rome. 6 pp.

Svenning, J.C., Normand, S. \& Kageyama, Y.M. -2008Glacial refugia of temperate trees in Europe: insights from species distribution modelling - J. Ecol. 96: 1117-1127.

Svenning, J.C., Fløjgaard, C., Marske, K., Nógues-Bravo, D. \& Normand, S. - 2011 - Applications of species distribution modeling to paleobiology - Quat. Sci. Rev. 30(21-22): 2930-2947. 
Thomas, P.A. \& Polwart, A. - 2003- Biological flora of the British Isles. Taxus baccata L. - J. Ecol. 91: 489-524

Thuiller, W., Albert, C., Araújo, M.B., Berry, P.M., Cabeza, M., Guisan, A., Hickler, T., Midgley, G.F., Paterson, J., Schurr, F.M., Sykes, M.T. \& Zimmermann, N.E. -2008 - Predicting global change impacts on plant species' distributions: future challenges - Persp. Plant Ecol. Evol. Syst. 9: 137-152.

Tinner, W. \& Lotter, A.F. -2006- Holocene expansions of Fagus sylvatica and Abies alba in Central Europe: where are we after eight decades of debate? - Quat. Sci. Rev. 25: 526-549.

Turner, R., Roberts, N. \& Jones, M.D. -2008 - Climatic pacing of Mediterranean fire histories from lake sedimentary microcharcoal - Global Planet. Change 63: 317-324.

Tzedakis, P.C. -2007- Seven ambiguities in the Mediterranean palaeoenvironmental narrative - Quat. Sci. Rev. 26: 2042-2066.

Ubanell, A.G. - 1994 - Los modelos tectónicos del Sistema Central Español - Cad. Lab. Xeol. Laxe 19: 249260.

Valladares, F. \& Niinemets, U. - 2008 - Shade tolerance, a key plant feature of complex nature and consequences - Ann. Rev. Ecol. Evol. Syst. 39:237-257.

Valsecchi, V., Finsinger, W., Tinner, W. \& Ammann, B. 2008 - Testing the influence of climate, human impact and fire on the Holocene population expansion of Fagus sylvatica in the southern Prealps (Italy) - Holocene 18(4): 603-614.

Van der Brink, L.M. \& Janssen, C.R. - 1985 - The effect of human activities during cultural phases on the development of montane vegetation in the Serra da Estrela, Portugal - Rev. Palaeobot. Palynol. 44: 193-215.

Van der Knaap, W.O. \& van Leeuwen, J.F.N. -1995- Holocene vegetation and degradation as responses to climatic change and human activity in the Serra da Estrela, Portugal - Rev. Palaeobot. Palynol. 89: 153-211.

Van Der Knaap, W.O., van Leeuwen, J.F.N. \& Ammann, B. -2004- The first rise and fall of Fagus sylvatica and interactions with Abies alba at Faulenseemoos (Swiss Plateau) 6900-6000 cal yr BP - Acta Palaeobot. 44(2): 249-266.

Vanniere, B., Power, M.J., Roberts, N., Tinner, W., Carrion, J., Magny, M., Bartlein, P., Colombaroli, D., Daniau, A.L., Finsinger, W., Gil-Romera, G., Kaltenrieder, P., Pini, R., Sadori, L., Turner, R., Valsecchi, V. \& Vescovi, E. 2011 - Circum-Mediterranean fire activity and climate changes during the mid-Holocene environmental transition (8500-2500 cal. BP) - Holocene 21(1): 53-73.

van Geel, B., van der Plicht, J., Kilian, M.R., Klaver, E.R., Kouwenberg, J.H.M., Renssen, H., Reynaud-Farrera, L., Waterbolk, H.T. $-1998-$ The sharp rise of $\Delta 14 \mathrm{C}$ ca. $800 \mathrm{cal}$ BC: possible causes, related climatic teleconnec- tions and the impact on human environments - Radiocarbon 40: 535-550.

Vázquez, R. - 1992- Evolución del paisaje vegetal durante el Cuaternario reciente en la zona central y oriental de la Sierra de Guadarrama a partir del análisis palinológico - Mem. Doc. (inéd.). Univ. Alcalá de Henares, Alcalá de Henares.

Vicent, J.M. - 1995 - Early social complexity in Iberia: some theorical remarks - In: Lillios, K.T. (Ed.). The origins of complex societies in late prehistoric Iberia. Pp. 177-183. Ann Arbor, Michigan.

Vicent, J.M., - 1998 - La prehistoria del modo tributario de producción - Hispania 58: 823-839

von Wühlisch, G. -2008- EUFORGEN Technical Guidelines for genetic conservation and use for European beech (Fagus sylvatica) - Bioversity International, Rome.

Walker, M.J.C., Berkelhammer, M., Björck, S., Cwynar, L.C., Fisher, D.A., Long, A.J., Lowe, J.J., Newnham, R.M., Rasmussen, S.O.\& Weiss, H. -2012- Formal subdivision of the Holocene Series/Epoch: a Discussion Paper by a Working Group of INTIMATE (Integration of ice-core, marine and terrestrial records) and the Subcommission on Quaternary Stratigraphy (International Commission on Stratigraphy) -- J. Quat. Sci. 27(7): 649-659.

Wanner, H., Beer, J., Bütikofer, J., Crowley, T.J., Cubasch, U., Flückiger, J., Goosse, H., Grosjean, M., Joos, F., Kaplan, J.O., Küttel, M., Müller, S.A., Prentice, I.C., Solomina, O., Stocker, T.F., Tarasov, P., Wagner, M., \& Widmann, M. -2008 - Mid- to Late Holocene climate change: an overview, Quat. Sci. Rev. 27: 1791-1828.

Wanner, H., Solomina, O., Grosjean, M., Ritz, S.P., \& Jetel, M. $-2011-$ Structure and origin of Holocene cold events - Quat. Sci. Rev. 30(21-22): 3109-3123.

Willis, K., Rudner, E. \& Sümegi, P. - 2000 - The Full-Glacial Forests of Central and Southeastern Europe - Quat. Res. 53: 203-213.

Willis, K.J. \& MacDonald, G.M. -2011 - Long-term ecological records and their relevance to climate change predictions for a warmer world - Annu. Rev. Ecol. Evol. S. 42: 267-287.

Willkomm, M. - 1896- Die vegetation der erde. Grundzüge der pflanzen verbreitung auf der Iberischen Halbinse - Verlag von Wilhelm Engelmann. Leipzig

Willner, W., Pietro, R. \& Bergmeier, E. -2009- Phytogeographical evidence for post-glacial dispersal limitation of European beech forest species - Ecography 32: 1011-1018

Wisz, M.S. \& Guisan, A. -2009- Do Pseudo-absence Selection Strategies Influence Species Distribution Models and Their Predictions? An Information-theoretic Approach Based on Simulated Data - BMC Ecology 9 (1): 8.

Zarek, M. -2009-RAPD analysis of genetic structure in four natural populations of Taxus baccata from southern Poland - Acta Biol. Cracov. ser. Bot. 51(2): 67-75. 